\title{
Lithium ions display weak interaction with amyloid-beta (A $\beta)$ peptides and have minor effects on their aggregation
}

\author{
Elina Berntsson ${ }^{1,2}$, Suman Paul', Faraz Vosough1, Sabrina B. Sholts ${ }^{3}$, Jüri Jarvet ${ }^{1,4}$, \\ Per M. Roos 5,6 , Andreas Barth1, Astrid Gräslund ${ }^{1}$ and Sebastian K. T. S. Wärmländer ${ }^{1} \square$
}

'Department of Biochemistry and Biophysics, Stockholm University, Sweden; 2Department of Chemistry and Biotechnology, Tallinn University of Technology, Estonia; ${ }^{3}$ Department of Anthropology, National Museum of Natural History, Smithsonian Institution, Washington, DC, USA; 4The National Institute of Chemical Physics and Biophysics, Tallinn, Estonia; Institute of Environmental Medicine, Karolinska Institutet, Stockholm, Sweden; ${ }^{6}$ Department of Clinical Physiology, Capio St. Göran Hospital, Stockholm, Sweden

\begin{abstract}
Alzheimer's disease (AD) is an incurable disease and the main cause of age-related dementia worldwide, despite decades of research. Treatment of $A D$ with lithium (Li) has shown promising results, but the underlying mechanism is unclear. The pathological hallmark of AD brains is deposition of amyloid plaques, consisting mainly of amyloid- $\beta(A \beta)$ peptides aggregated into amyloid fibrils. The plaques contain also metal ions of e.g. $\mathrm{Cu}, \mathrm{Fe}$, and $\mathrm{Zn}$, and such ions are known to interact with $A \beta$ peptides and modulate their aggregation and toxicity. The interactions between $A \beta$ peptides and $\mathrm{Li}^{+}$ions have however not been well investigated. Here, we use a range of biophysical techniques to characterize in vitro interactions between $A \beta$ peptides and $\mathrm{Li}^{+}$ions. We show that $\mathrm{Li}^{+}$ions display weak and non-specific interactions with $A \beta$ peptides, and have minor effects on $A \beta$ aggregation. These results indicate that possible beneficial effects of $\mathrm{Li}$ on AD pathology are not likely caused by direct interactions between $\mathrm{A} \beta$ peptides and $\mathrm{Li}^{+}$ions.
\end{abstract}

Keywords: Alzheimer's disease, protein aggregation, metal-protein binding, neurodegeneration, pharmaceutics

Received: 19 September, 2020; revised: 24 December, 2020; accepted: 03 January, 2021; available on-line: 28 April, 2021

@e-mail: seb@dbb.su.se

Acknowledgements of Financial Support: This work was supported by grants from the Swedish Alzheimer Foundation and the Swedish Research Council to AG, the Swedish Brain Foundation to $A G$ and $A B$, the Magnus Bergvall Foundation to SW and PR, the UIla-Carin Lindquist ALS Foundation to PR, and from Olle Engkvist's Foundation, the Stockholm Region, and Knut and Alice Wallenberg Foundation to $A B$.

Abbreviations: $A \beta$, amyloid- $\beta$; $A D$, Alzheimer's disease; AFM, Atomic force microscopy; CD, Circular dichroism; DMSO, Dimethyl sulfoxide; NMR, Nuclear magnetic resonance

\section{INTRODUCTION}

Alzheimer's disease (AD) is still an incurable disease and the main cause of age-related dementia worldwide (Querfurth \& LaFerla, 2010; Prince et al., 2015; Frozza et al., 2018), despite decades of research on putative drugs (Luo et al., 2013; Wärmländer et al., 2013; Decker \& Munoz-Torrero, 2016; Kisby et al., 2019). In addition to signs of neuroinflammation and oxidative stress (Agostinho et al., 2010; Al-Hilaly et al., 2013; Wang et al., 2014; Heppner et al., 2015; Regen et al., 2017), AD brains display characteristic lesions in the form of intracellular neurofibrillary tangles, consisting of aggregated hyperphosphorylated tau proteins (Goedert, 2018; Gibbons et al., 2019), and extracellular amyloid plaques, consisting mainly of insoluble fibrillar aggregates of amyloid- $\beta$ (A $\beta$ ) peptides (Glenner \& Wong, 1984; Querfurth \& LaFerla, $2010)$. These $A \beta$ fibrils and plaques are the end-product of an aggregation process (Querfurth \& LaFerla, 2010; Luo et al., 2016; Selkoe \& Hardy, 2016) that involves extra- and/or intracellular formation of intermediate, soluble, and likely neurotoxic $A \beta$ oligomers (Luo et al., 2014; Selkoe \& Hardy, 2016; Sengupta et al., 2016; Lee et al., 2017) that can spread from neuron to neuron via exosomes (Nath et al., 2012; Sardar Sinha et al., 2018).

The $A \beta$ peptides comprise $37-43$ residues and are intrinsically disordered in aqueous solution. They have limited solubility in water due to the hydrophobicity of the central and $C$-terminal $A \beta$ segments, which may fold into a hairpin conformation upon aggregation (Abelein et al., 2014; Baronio et al., 2019). The charged N-terminal segment is hydrophilic and readily interacts with cationic molecules and metal ions (Luo et al., 2013; Luo et al., 2014; Tiiman et al., 2016; Wallin et al., 2016; Wallin et al., 2017; Owen et al., 2019; Wallin et al., 2020), while the hydrophobic C-terminal segment can interact with membranes where $A \beta$ may exert its toxicity (Österlund et al., 2018; Wärmländer et al., 2019). The interactions between $A \beta$ and metal ions are of particular interest (Duce et al., 2011; Wärmländer et al., 2013; Mital et al., 2015; Wärmländer et al., 2019; Wallin et al., 2020), as altered metal concentrations indicative of metal dyshomeostasis are a prominent feature in the brains and fluids of AD patients (Wang et al., 2015; Szabo et al., 2016), and because $\mathrm{AD}$ plaques contain elevated amounts of metal ions of e.g. $\mathrm{Cu}, \mathrm{Fe}$, and $\mathrm{Zn}$ (Beauchemin \& Kisilevsky, 1998; Lovell et al., 1998; Miller et al., 2006).

Interestingly, although the role of metal ions in $\mathrm{AD}$ pathogenesis remains debated (Duce et al., 2011; Modgil et al., 2014; Chin-Chan et al., 2015; Mital et al., 2015; Adlard \& Bush, 2018; Huat et al., 2019; Wärmländer et al., 2019), monovalent ions of the alkali metal lithium [i.e., $\mathrm{Li}^{+}$ions] may provide beneficial effects to patients with neurodegenerative disorders such as amyotrophic lateral sclerosis (ALS) (Fornai et al., 2008; Morrison et al., 2013) or AD (Engel et al., 2008; Mauer et al., 2014; Sutherland \& Duthie, 2015; Decker \& Munoz-Torrero, 2016; Donix \& Bauer, 2016; Morris \& Berk, 2016; Kerr et al., 2018; Hampel et al., 2019; Kisby et al., 2019; Priebe \& Kanzawa, 2020). Lithium salts are commonly used in psychiatric medication, even though it is not understood how the $\mathrm{Li}^{+}$ions affect the molecular mechanisms underlying the psychiatric disorders (Dell'Osso et al., 2016). Unlike other pharmaceuticals, $\mathrm{Li}^{+}$is widely non-selective in its biochemical effects, possibly due to its general propen- 
sity to inhibit the many enzymes that have magnesium as a cofactor (Ge \& Jakobsson, 2018).

Cell and animal studies have provided clues regarding how $\mathrm{Li}^{+}$ions may affect the AD disease pathology (Nery et al., 2014; Sofola-Adesakin et al., 2014; Zhao et al., 2014; Budni et al., 2017; Habib et al., 2017; Cardillo et al., 2018; Kerr et al., 2018; Habib et al., 2019; Rocha et al., 2020; Wilson et al., 2020). Due to its ability to down-regulate translation, $\mathrm{Li}^{+}$caused a reduction in protein synthesis and thus $A \beta_{42}$ levels in an adult-onset Drosophila model of AD (Sofola-Adesakin et al., 2014) $\mathrm{Li}^{+}$reduces $\mathrm{A} \beta$ production by affecting the processing/cleavage of the amyloid- $\beta$ precursor protein (A $\beta P P)$ in cells and mice, presumably by down-regulating the levels of phosphorylated AßPP. A main target of $\mathrm{Li}^{+}$is the glycogen synthase kinase 3-beta (GSK-3 $\beta$ ) (Ryves \& Harwood, 2001) which is implicated in AD pathogenesis (Caccamo et al., 2007; Forlenza et al., 2014). In A PPP-transgenic mice, reduced activation of the GSK-3 $\beta$ enzyme was associated with decreased levels of A $\beta P P$ phosphorylation that resulted in decreased $A \beta$ production (Rockenstein et al., 2007). One study on mice with traumatic brain injury reported that $\mathrm{Li}^{+}$-treatment improved spatial learning and reduced $A \beta$ production, possibly by reducing the levels of both $\mathrm{A} \beta \mathrm{PP}$ and the AßPP-cleaving enzyme BACE1 ( $\mathrm{Yu}$ et al., 2012). More recent mice studies have reported that treatment with $\mathrm{Li}^{+}$ions improved $\mathrm{A} \beta$ clearance from the brain (Pan et al., 2018), reduced oxidative stress levels (Xiang et al., 2020), improved spatial memory (Habib et al., 2019), and reduced the amounts of $A \beta$ plaques and phosphorylated tau while also improving spatial memory (Liu et al., 2020).

Only a few studies have however investigated how $\mathrm{Li}^{+}$ions could affect the molecular events that appear to underlie $\mathrm{AD}$ pathology, such as $\mathrm{A} \beta$ aggregation. One study showed that increased ionic strength, i.e. $150 \mathrm{mM}$ of $\mathrm{NaF}, \mathrm{NaCl}$, or $\mathrm{LiCl}$, significantly accelerated the kinetics of $A \beta$ amyloid aggregation, by promoting surfacecatalyzed secondary nucleation reactions (Abelein et al., 2016). Another recent study used molecular dynamics simulations to find small but distinct differences in how the three monovalent $\mathrm{Li}^{+}, \mathrm{N}^{+}$, and $\mathrm{K}^{+}$ions interact with A $\beta$ oligomers (Huraskin \& Horn, 2019). A therapeutic effect of $\mathrm{Li}^{+}$on $\mathrm{A} \beta$ plaque quality and toxicity has been reported in mice, where $\mathrm{Li}^{+}$treatment before pathology onset induced smaller plaques with higher $A \beta$ compaction, reduced oligomeric-positive halo, and attenuated capacity to induce neuronal damage (Trujillo-Estrada et al., 2013). One hypothesis is that these neuroprotective effects of $\mathrm{Li}^{+}$could be mediated by modifications of the plaque toxicity through the astrocytic release of heat shock proteins (Trujillo-Estrada et al., 2013).

Here, we use a range of biophysical techniques to characterize the in vitro interactions between $\mathrm{Li}^{+}$ions and $A \beta$ peptides, and how such interactions affect the $A \beta$ amyloid aggregation processes and fibril formation.

\section{MATERIALS AND METHODS}

\section{Sample preparation}

Recombinant $A \beta_{40}$ peptides were purchased from AlexoTech AB (Umeå, Sweden) in either unlabeled or uniformly ${ }^{15} \mathrm{~N}$-labeled form. The lyophilized peptides were stored at $-80^{\circ} \mathrm{C}$. Samples were dissolved to monomeric form immediately before each measurement. The peptides were first dissolved in $10 \mathrm{mM} \mathrm{NaOH}$, and then sonicated in an ice-bath to avoid having pre-formed ag- gregates in the sample solutions. Next, the samples were diluted in $20 \mathrm{mM}$ buffer of either sodium phosphate or MES (2-[N-morpholino]ethanesulfonic acid). All preparation steps were performed on a bed of ice, and the peptide concentration was determined by weight. $\mathrm{LiCl}$ salt was purchased from Merck \& Co. Inc. (USA), and MES hydrate was purchased from Sigma-Aldrich (USA).

Synthetic $A \beta_{42}$ peptides were purchased from JPT Peptide Technologies (Germany) and used to prepare monomeric solutions via size exclusion chromatography. $1 \mathrm{mg}$ of lyophilized $A \beta_{42}$ powder was dissolved in $250 \mathrm{~mL}$ DMSO (dimethyl sulfoxide). A Sephadex G-250 HiTrap desalting column (GE Healthcare, Uppsala) was equilibrated with $5 \mathrm{mM} \mathrm{NaOH}$ solution $(\mathrm{pH}=12.3)$, and washed with $10-15 \mathrm{~mL}$ of $5 \mathrm{mM} \mathrm{NaOD}, \mathrm{pD}=12.7$ (Glasoe \& Long, 1960) solution. The peptide solution in DMSO was applied to the column, followed by injection of $1.25 \mathrm{~mL}$ of $5 \mathrm{mM} \mathrm{NaOD}$. Collection of peptide fractions in $5 \mathrm{mM} \mathrm{NaOD}$ on ice was started at a $1 \mathrm{mg} /$ $\mathrm{mL}$ flow rate. Ten fractions of $1 \mathrm{~mL}$ volumes were collected in $1.5 \mathrm{~mL}$ Eppendorf tubes. The absorbance for each fraction at $280 \mathrm{~nm}$ was measured with a NanoDrop instrument (Eppendorf, Germany), and peptide concentrations were determined using a molar extinction coefficient of $1280 \mathrm{M}^{-1} \mathrm{~cm}^{-1}$ for the single Tyr in $\mathrm{A} \beta_{42}$ (Edelhoch, 1967). The peptide fractions were flash-frozen in liquid nitrogen, covered with argon gas on top in $1.5 \mathrm{~mL}$ Eppendorf tubes, and stored at $-80^{\circ} \mathrm{C}$ until used. Sodium dodecyl sulfate (SDS)-stabilized $\mathrm{A} \beta_{42}$ oligomers of two well-defined sizes (approximately tetramers and dodecamers) were prepared according to a previously published protocol (Barghorn et al., 2005), but in $\mathrm{D}_{2} \mathrm{O}$, at 4-fold lower peptide concentration and without the original dilution step (Vosough \& Barth, 2021). The reaction mixtures $\left(100 \mu \mathrm{M} \mathrm{A} \beta_{42}\right.$ in PBS and containing $0.05 \%$ or $0.2 \%$ SDS) were incubated together with $0-10 \mathrm{mM} \mathrm{LiCl}$ at $37^{\circ} \mathrm{C}$ for 24 hours, and then flash-frozen in liquid nitrogen and stored at $-20^{\circ} \mathrm{C}$ for later analysis.

\section{Thioflavin T kinetics}

A FLUOstar Omega microplate reader (BMG LABTECH, Germany) was used to monitor the effect of $\mathrm{Li}^{+}$ions on $\mathrm{A} \beta$ aggregation kinetics. $20 \mu \mathrm{M}$ Monomeric $A \beta_{40}$ peptides were incubated in $20 \mathrm{mM}$ MES buffer, $\mathrm{pH} 7.35$, together with different concentrations of $\mathrm{LiCl}(0,20 \mu \mathrm{M}, 200 \mu \mathrm{M}, 2000 \mu \mathrm{M})$ and $50 \mu \mathrm{M}$ Thioflavin $\mathrm{T}$ (ThT) ThT is a fluorescent benzothiazole dye, and its fluorescence intensity increases when bound to amyloid aggregates (Gade Malmos et al., 2017). Samples were placed in a 96-well plate where the sample volume in each well was $100 \mu \mathrm{L}$, four replicates per $\mathrm{Li}^{+}$concentration were measured, the temperature was $+37^{\circ} \mathrm{C}$, excitation of the ThT dye was at $440 \mathrm{~nm}$, the ThT fluorescence emission at $480 \mathrm{~nm}$ was measured every five minutes, each five-minute cycle involved 140 seconds of shaking at $200 \mathrm{rpm}$, the samples were incubated for a total of 15 hours, and the assay was repeated three times. To derive parameters for the aggregation kinetics, the ThT fluorescence curves were fitted to the sigmoidal equation 1 :

$$
F(t)=F_{0}+m_{0} \cdot t+\frac{F_{\infty}+m_{\infty} \cdot t}{1+\exp -\left[\left(t-t_{1 / 2}\right) / \tau\right]}
$$

where $F_{0}$ and $F_{\infty}$ are the intercepts of the initial and final fluorescence intensity baselines, $\mathrm{m}_{0}$ and $\mathrm{m}_{\infty}$ are the slopes of the initial and final baselines, $t_{1 / 2}$ is the time needed to reach halfway through the elongation phase 
(i.e., aggregation half-time), and $\tau$ is the elongation time constant (Gade Malmos et al., 2017). The apparent maximum rate constant, $r_{\max }$, for the growth of fibrils is given by $1 / \tau$.

\section{Tyrosine fluorescence quenching}

The binding affinity between $A \beta_{40}$ peptides and $\mathrm{Li}^{+}$ ions was evaluated from $\mathrm{Cu}^{2+} / \mathrm{Li}^{+}$binding competition experiments (Wallin et al., 2020). The affinity of the $\mathrm{Cu}^{2+} \cdot \mathrm{A} \beta_{40}$ complex was measured via the quenching effect of $\mathrm{Cu}^{2+}$ ions on the intrinsic fluorescence of Y10, which is the only fluorophore in native $A \beta$ peptides. The fluorescence emission intensity at $305 \mathrm{~nm}$ (excitation wavelength $276 \mathrm{~nm}$ ) was recorded at $20^{\circ} \mathrm{C}$ using a Jobin Yvon Horiba Fluorolog 3 fluorescence spectrophotometer (Longjumeau, France). The titrations were carried out by consecutive additions of $0.8-3.2 \mu \mathrm{L}$ aliquots of either 2,10 , or $50 \mathrm{mM}$ stock solutions of $\mathrm{CuCl}_{2}$ to $800 \mu \mathrm{L}$ of

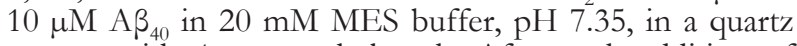
cuvette with $4 \mathrm{~mm}$ path length. After each addition of $\mathrm{CuCl}_{2}$ the solution was stirred for 30 seconds before recording fluorescence emission spectra. Copper titrations were conducted for $A \beta_{40}$ samples both in the absence and the presence of $1 \mathrm{mM} \mathrm{LiCl}$. The dissociation constant of the $\mathrm{Cu}^{2+} \cdot \mathrm{A} \beta_{40}$ complex was determined by fitting the $\mathrm{Cu}^{2+}$ titration data to equation 2 :

$$
\begin{aligned}
\mathrm{I}= & \mathrm{I}_{0}+\frac{\mathrm{I}_{\infty}-\mathrm{I}_{0}}{2 \cdot[\mathrm{A} \beta]} \cdot\left(\left(\mathrm{K}_{\mathrm{D}}+[\mathrm{Cu}]+[\mathrm{A} \beta]\right)-\right. \\
& \left.\sqrt{\left(\mathrm{K}_{\mathrm{D}}+[\mathrm{Cu}]+[\mathrm{A} \beta]\right)^{2}-4 \cdot[\mathrm{Cu}] \cdot[\mathrm{A} \beta]}\right)-k \cdot[\mathrm{Cu}]
\end{aligned}
$$

where $I_{0}$ is the initial fluorescence intensity without $\mathrm{Cu}^{2+}$ ions, $I_{\infty}$ is the steady-state (saturated) intensity at the end of the titration series, $[A \beta]$ is the peptide concentration, $[\mathrm{Cu}]$ is the concentration of added $\mathrm{Cu}^{2+}$ ions, $\mathrm{K}_{\mathrm{D}}$ is the dissociation constant of the $\mathrm{Cu}^{2+} \cdot \mathrm{A} \beta_{40}$ complex, and $\mathrm{k}$ is a constant accounting for the concentration-dependent quenching effect induced by free (non-bound) $\mathrm{Cu}^{2+}$ ions that may collide with the Y10 residue (Lindgren et al., 2013). This model assumes a single binding site. As no corrections for buffer conditions are made, i.e. in terms of possible interactions between the metal ions and the buffer, the calculated dissociation constant should be considered to be apparent.

\section{Atomic force microscopy imaging}

Samples of $20 \mu \mathrm{M} \mathrm{A} \beta_{40}$ in $5 \mathrm{mM}$ MES buffer (total volume $100 \mu \mathrm{L}, \mathrm{pH} 7.35$ ) with either $0,20 \mu \mathrm{M}, 200 \mu \mathrm{M}$ or $2 \mathrm{mM} \mathrm{LiCl}$ were put in small Eppendorf tubes and incubated for 72 hours at $37^{\circ} \mathrm{C}$ under continuous shaking at $300 \mathrm{rpm}$. A droplet $(1 \mu \mathrm{L})$ of incubated solution was then placed on a fresh silicon wafer (Siegert Wafer $\mathrm{GmbH}$, Germany) and left to dry for 2 minutes. Next, $10 \mathrm{uL}$ of Milli-Q $\mathrm{H}_{2} \mathrm{O}$ was carefully added to the semidried sample droplet and soaked immediately with a lintfree wipe, to remove excess salts in a mild manner. The wafer was left to dry in a covered container to protect it from dust, and atomic force microscopy (AFM) images were recorded on the same day. A neaSNOM scatteringtype near-field optical instrument (Neaspec GmbH, Germany) was used to collect the AFM images under tapping mode ( $\Omega: 280 \mathrm{kHz}$, tapping amplitude $50-55 \mathrm{~nm}$ ) using Pt/Ir-coated monolithic ARROW-NCPt Si tips (NanoAndMore $\mathrm{GmbH}$, Germany) with tip radius $<10$ $\mathrm{nm}$. Images were acquired on $2.5 \times 2.5 \mu \mathrm{m}$ scan-areas $(200 \times 200$-pixel size) under optimal scan-speed (i.e., 2.5 $\mathrm{ms} / \mathrm{pixel})$. The recorded images were minimally pro- cessed using the Gwyddion software where a basic plane leveling was performed (Nečas \& Klapetek, 2012).

\section{Nuclear magnetic resonance spectroscopy}

An Avance $700 \mathrm{MHz}$ nuclear magnetic resonance (NMR) spectrometer (Bruker Inc., USA) equipped with a cryoprobe was used to investigate possible interactions between $\mathrm{Li}^{+}$ions and monomeric $\mathrm{A} \beta_{40}$ peptides at the atomic level. 2D ${ }^{1} \mathrm{H}-{ }^{15} \mathrm{~N}-\mathrm{HSQC}$ spectra of $92.4 \mu \mathrm{M}$ monomeric ${ }^{15} \mathrm{~N}$-labeled $\mathrm{A} \beta_{40}$ peptides were recorded at $5^{\circ} \mathrm{C}$ with $90 / 10 \mathrm{H}_{2} \mathrm{O} / \mathrm{D}_{2} \mathrm{O}$, either in $20 \mathrm{mM}$ MES buffer at $\mathrm{pH} 7.35$ or in $1 \mathrm{x}$ PBS buffer $(137 \mathrm{mM} \mathrm{NaCl}, 2.7$ $\mathrm{mM} \mathrm{KCl}$, and $10 \mathrm{mM}$ phosphate $\mathrm{pH}$ 7.4), before and after additions with LiCl. Diffusion measurements were performed on a sample of $55 \mu \mathrm{M}$ unlabeled monomeric $\mathrm{A} \beta_{40}$ peptide in $20 \mathrm{mM}$ sodium phosphate buffer, $100 \%$ $\mathrm{D}_{2} \mathrm{O}, \mathrm{pD} 7.5$, at $5^{\circ} \mathrm{C}$, before and after additions with $\mathrm{LiCl}$ dissolved in $\mathrm{D}_{2} \mathrm{O}$. The diffusion experiments employed pulsed field gradients (PFG:s) according to previously described methods (Danielsson et al., 2002), and methyl group signals between 0.7-0.4 ppm were integrated, evaluated, and corrected for the viscosity of $\mathrm{D}_{2} \mathrm{O}$ at $5^{\circ} \mathrm{C}$ (Cho et al., 1999). All NMR data was processed with the Topspin version 3.6.2 software, and the HSQC crosspeak assignment for $A \beta_{40}$ in buffer is known from previous studies (Danielsson et al., 2006).

\section{Circular dichroism spectroscopy}

Circular dichroism (CD) spectra of $20 \mu \mathrm{M} A \beta_{40}$ peptides in $20 \mathrm{mM}$ sodium phosphate buffer, $\mathrm{pH} 7.35$, were recorded at $20^{\circ} \mathrm{C}$ using a Chirascan $\mathrm{CD}$ spectrometer (Applied Photophysics, UK) and a quartz cuvette with an optical path length of $2 \mathrm{~mm}$. Measurements were done between 190-250 nm, with a step size of $1 \mathrm{~nm}$ and a sampling time of $4 \mathrm{~s}$ per data point. First, a spectrum was recorded for $A \beta_{40}$ alone. Next, micelles of $50 \mathrm{mM}$ SDS were added to create a membrane-mimicking environment. Finally, $\mathrm{LiCl}$ was titrated to the sample in steps up to a concentration of $512 \mu \mathrm{M}$.

\section{Blue native polyacrylamide gel electrophoresis}

Homogeneous solutions of $80 \mu \mathrm{M} \quad \mathrm{A} \beta_{42}$ oligomers (Vosough \& Barth, 2021) prepared in presence and absence of $0-10 \mathrm{mM} \mathrm{Li}^{+}$ions were analyzed with blue native polyacrylamide gel electrophoresis (BN-PAGE) using the Invitrogen system. 4-16\% Bis-Tris Novex gels (ThermoFisher Scientific, USA) were loaded with $10 \mu \mathrm{L}$ of $A \beta_{42}$ oligomer samples alongside the Amersham High Molecular Weight calibration kit for native electrophoresis (GE Healthcare, USA). The gels were run at $4^{\circ} \mathrm{C}$ using the electrophoresis system according to the Invitrogen instructions (ThermoFisher Scientific, USA), and then stained using the Pierce Silver Staining kit according to the instructions (ThermoFisher Scientific, USA).

\section{Infrared spectroscopy}

Fourier-transformed infrared (FTIR) spectra of $A \beta_{42}$ oligomers were recorded in transmission mode on a Tensor 37 FTIR spectrometer (Bruker Optics, Germany) equipped with a sample shutter and a liquid nitrogen-cooled MCT detector. The unit was continuously purged with dry air during the measurements. 8-10 $\mu \mathrm{L}$ of the $80 \mu \mathrm{M} \mathrm{A} \beta_{42}$ oligomer samples, containing 0-10 $\mathrm{mM} \mathrm{LiCl}$, were put between two flat $\mathrm{CaF}_{2}$ discs separated by a $50 \mu \mathrm{m}$ plastic spacer covered with vacuum grease at the periphery. The assembled discs were mounted in a holder inside the instrument's sam- 
ple chamber. The samples were allowed to sit for at least 15 minutes after closing the chamber lid, to avoid interference from $\mathrm{CO}_{2}$ and $\mathrm{H}_{2} \mathrm{O}$ vapor. FTIR spectra were recorded at room temperature in the 1900-800 $\mathrm{cm}^{-1}$ range, with 300 scans for both background and sample spectra, using a $6 \mathrm{~mm}$ aperture and a resolution of $2 \mathrm{~cm}^{-1}$. The light intensities above $2200 \mathrm{~cm}^{-1}$ and below $1500 \mathrm{~cm}^{-1}$ were blocked with respectively a germanium filter and a cellulose membrane (Baldassarre $\&$ Barth, 2014). The spectra were analyzed and plotted with the OPUS 5.5 software, and second derivatives were calculated with a $17 \mathrm{~cm}^{-1}$ smoothing range.

\section{RESULTS}

ThT fluorescence: influence of $\mathrm{Li}^{+}$ions on $A \beta_{40}$ aggregation

The fluorescence intensity of the amyloid-marker molecule ThT was measured when $20 \mu \mathrm{M} A \beta_{40}$ samples were incubated for 15 hours together with different concentrations of $\mathrm{LiCl}$ (Fig. 1) Fitting Eq. 1 to the ThT fluorescence curves yielded the kinetic parameters $t_{1 / 2}$ (aggregation half-time) and $r_{\max }$ (maximum aggregation rate) (Fig. 1; Table 1). For $20 \mu \mathrm{M}$ $\mathrm{A} \beta_{40}$ alone, the aggregation half-time is approximately 3.7 hours under the experimental conditions used, and the maximum aggregation rate is 0.5 hours $^{-1}$ (Table $1)$. These kinetic parameters are not much affected by addition of $\mathrm{LiCl}$ in $1: 1$ or $10: 1 \mathrm{Li}^{+}: \mathrm{A} \beta$ ratios. At the $\mathrm{Li}^{+}: \mathrm{A} \beta$ ratio of $100: 1$, the $r_{\max }$ value remains largely unaffected while the aggregation half-time is increased to almost 5 hours (Fig 1; Table 1). The observation that a $\mathrm{Li}^{+}: \mathrm{A} \beta$ ratio of $100: 1$ is required to shift the ThT curve clearly shows that $\mathrm{Li}^{+}$ions do not have a strong effect on the $A \beta_{40}$ aggregation kinetics.

\section{AFM imaging: effects of $\mathrm{Li}^{+}$ions on the morphology of} $A \beta_{40}$ aggregates

AFM images (Fig. 2) were recorded for the aggregation products of $20 \mu \mathrm{M} \mathrm{A} \beta_{40}$ peptide, incubated for three
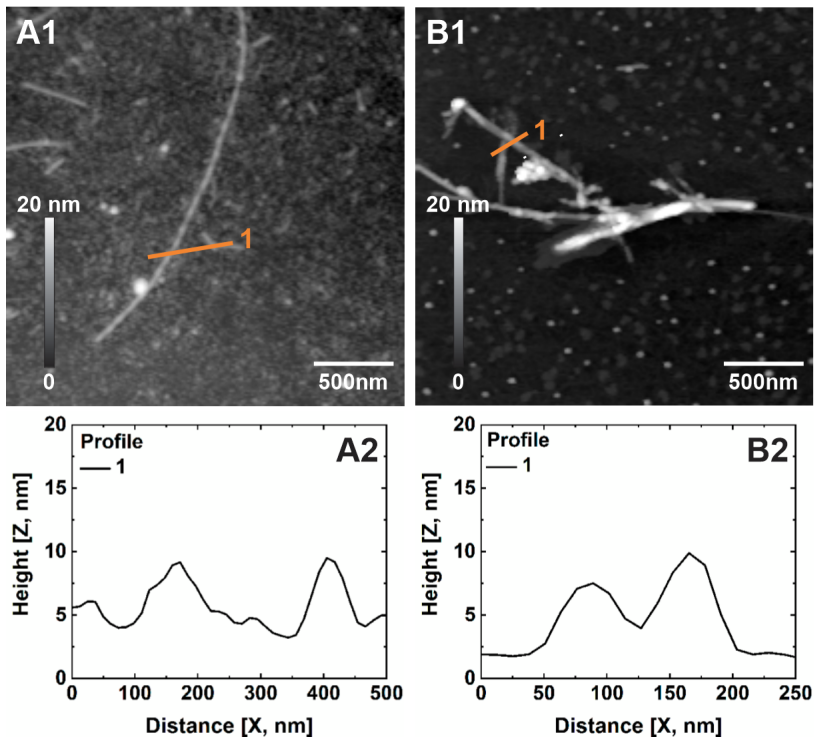

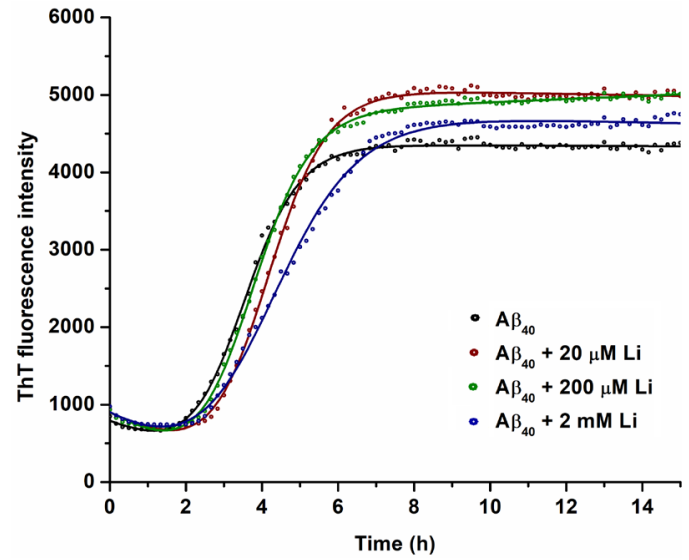

Figure 1. Amyloid fibril formation monitored by ThT aggregation.

Samples of $20 \mu \mathrm{MA} \beta_{40}$ peptides in $20 \mathrm{mM}$ MES buffer, pH 7.35, were incubated at $+37^{\circ} \mathrm{C}$ together with $50 \mu \mathrm{M}$ Thioflavin-T and different concentrations of LiCl: $0 \mu \mathrm{M}$ - black; $20 \mu \mathrm{M}$ - red; 200 $\mu \mathrm{M}$ - green; $2 \mathrm{mM}$ - blue. The circles represent average data points for four replicates, while the solid lines are derived from fitting to Eq. 1.

Table 1. Kinetic parameters for $A \beta_{40}$ fibril formation, i.e. aggregation half-time $\left(t_{1 / 2}\right)$ and maximum aggregation rate $\left(r_{\text {max }}\right)$, derived from fitting the curves in Fig. 1 to Eq. 1.

\begin{tabular}{|c|c|c|c|c|}
\hline & $20 \mu \mathrm{M} \mathrm{A} \beta_{40}$ & 1:1 Li+:A $\beta$ & $10: 1 \mathrm{Li}^{+}: \mathrm{A} \beta$ & $100: 1 \mathrm{Li}^{+}: \mathrm{A} \beta$ \\
\hline $\begin{array}{l}\mathrm{t}_{1 / 2} \\
\text { [hours] }\end{array}$ & $3.7 \pm 0.7$ & $3.6 \pm 2.1$ & $3.8 \pm 0.6$ & $4.9 \pm 1.3$ \\
\hline $\begin{array}{l}r_{\max } \\
\text { [hours } \\
\text { [-1] }\end{array}$ & $0.5 \pm 0.1$ & $0.4 \pm 0.2$ & $0.5 \pm 0.2$ & $0.4 \pm 0.1$ \\
\hline
\end{tabular}

days without or with $\mathrm{LiCl}$. The control sample without $\mathrm{Li}^{+}$displays long $(>2 \mu \mathrm{m})$ amyloid fibrils that are around $6 \mathrm{~nm}$ thick, together with small $(<2 \mathrm{~nm})$ aggregate particles that may be protofibrils (Fig. 2A). The distribution and sizes of these aggregates are rather typical for $\mathrm{A} \beta_{40}$ aggregates formed in vitro (Luo et al., 2014). The $\mathrm{A} \beta_{40}$ samples incubated in the presence of different concentrations of $\mathrm{Li}^{+}$ions display amyloid fibrils of similar
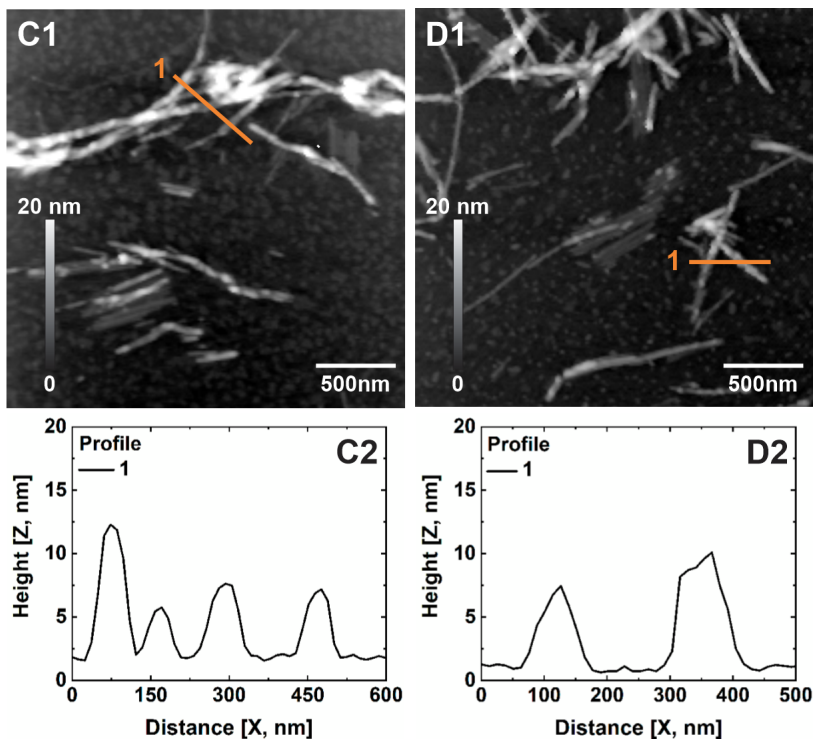

Figure 2. Solid state AFM images (A1-D1) of aggregates of $20 \mu \mathrm{M} \mathrm{A} \beta_{4}$ incubated in $5 \mathrm{mM}$ MES buffer, pH 7.35, for 72 hours at $+37^{\circ} \mathrm{C}$ with $300 \mathrm{rpm}$ shaking, together with different concentrations of $\mathrm{LiCl}$.

(A) control sample - no LiCl; (B) $20 \mu \mathrm{M} \mathrm{LiCl;}$ (C) $200 \mu \mathrm{M} \mathrm{LiCl;}$ (D) $2 \mathrm{mM} \mathrm{LiCl}$. The height profile graphs (A2-D2) below the AFM images correspond to the cross-sections of $A \beta_{40}$ fibrils shown as orange lines in the AFM images. 


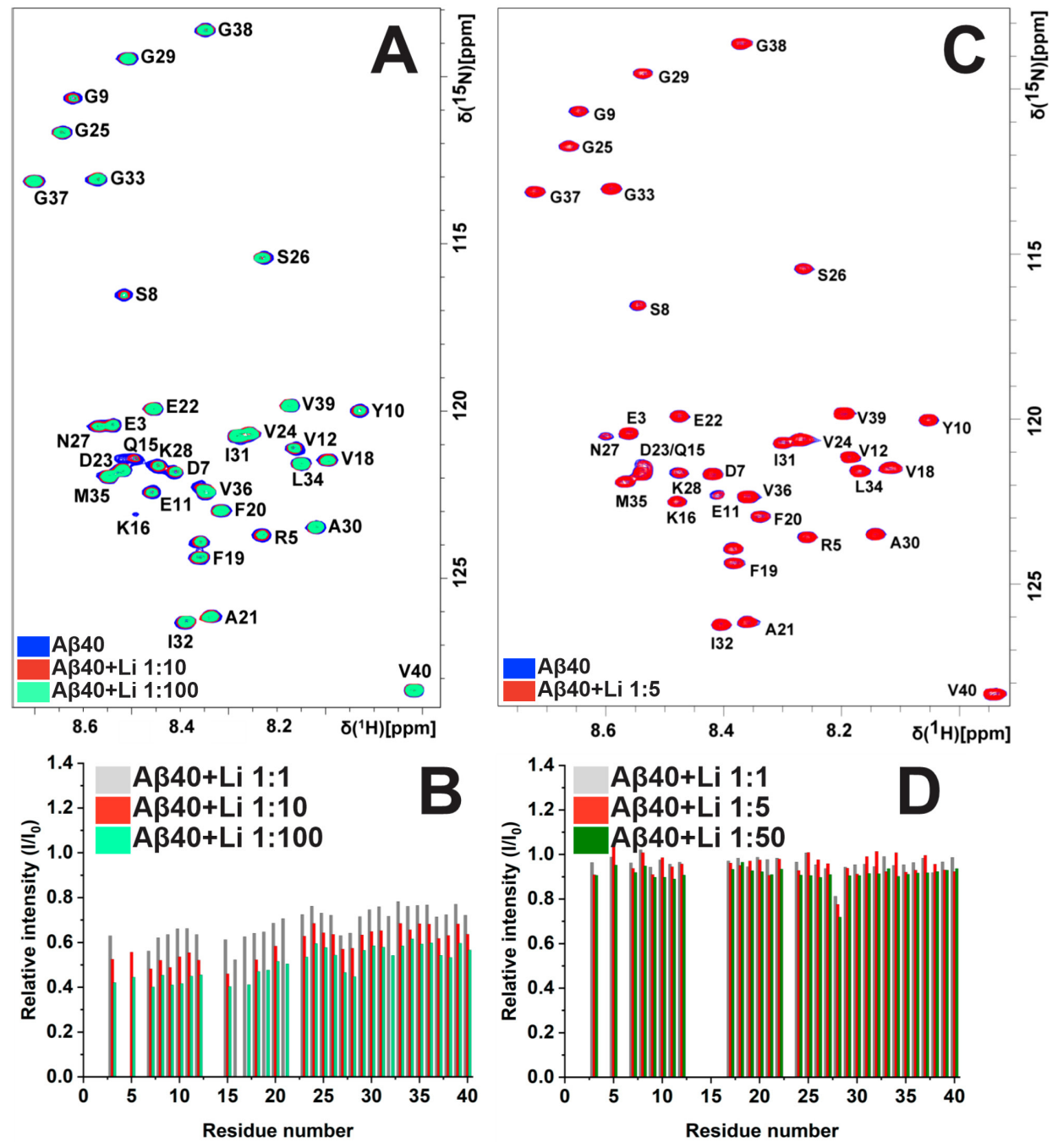

Figure 3. NMR experiments for interactions between $A \beta_{40}$ monomers and $\mathrm{Li}^{+}$ions.

(A) $2 \mathrm{D}{ }^{1} \mathrm{H}-{ }^{15} \mathrm{~N}-\mathrm{HSQC}$ spectra of $92.4 \mu \mathrm{M}{ }^{15} \mathrm{~N}$-labeled $\mathrm{A} \beta_{40}$ peptides in $20 \mathrm{mM}$ MES buffer, $\mathrm{pH} 7.35$ at $+5^{\circ} \mathrm{C}$, recorded for $\mathrm{A} \beta_{40}$ peptides alone (dark sky blue) and in the presence of either $924 \mu \mathrm{M} \mathrm{LiCl} \mathrm{(1:10} \mathrm{AB:Li} \mathrm{ratio;} \mathrm{passion} \mathrm{red)} \mathrm{or} 9.24 \mathrm{mM} \mathrm{LiCl} \mathrm{(1:100} \mathrm{A \beta :Li} \mathrm{ratio;} \mathrm{Robin} \mathrm{egg}$ blue). (B) Relative intensities of $A \beta_{40}$ residue crosspeaks shown in (A), after addition of LiCl in 1:1, 1:10, and 1:100 AB:Li ratios. (C and D) similar experiments as in A and $B$, but carried out in the presence of $1 x$ PBS buffer, and for A $A: L i$ ratios of 1:1, 1:5, and 1:50.

size and shape, although these fibrils are more densely packed and they appear to be more numerous (Fig. 1B, $1 \mathrm{C}, 1 \mathrm{D})$. Compared to the control sample, there are fewer small $(<2 \mathrm{~nm})$ aggregate particles in the samples incubated together with $\mathrm{Li}^{+}$ions in $10: 1$ and $100: 1 \mathrm{Li}^{+}: \mathrm{A} \beta$ ratios. This suggests that $\mathrm{Li}^{+}$ions may induce some differences in the $A \beta_{40}$ aggregation process.

\section{NMR spectroscopy: interactions between $\mathrm{Li}^{+}$ions and $A \beta_{40}$ monomers}

High-resolution liquid phase NMR experiments were conducted to investigate if residue-specific molecular interactions could be observed between $\mathrm{Li}^{+}$ions and monomeric $\mathrm{A} \beta_{40}$ peptides. 2D ${ }^{1} \mathrm{H}-{ }^{15} \mathrm{~N}-\mathrm{HSQC}$ spectra showing the amide crosspeak region for $92.4 \mu \mathrm{M}$ monomeric ${ }^{15} \mathrm{~N}$ labeled $A \beta_{40}$ peptides are presented in Fig. $3 \mathrm{~A}$, before and after addition of $\mathrm{LiCl}$ in 1:1, 1:10, and 1:100 $\mathrm{A} \beta: \mathrm{Li}^{+}$ ratios in $20 \mathrm{mM}$ MES buffer, 7.35. Addition of $\mathrm{Li}^{+}$ions induces loss of signal intensity mainly for amide crosspeaks corresponding to residues in the N-terminal half of the peptide, indicating selective $\mathrm{Li}^{+}$interactions in this region (Fig. 3B). The effects are clearly concentrationdependent. Because $\mathrm{Li}^{+}$ions are not paramagnetic, this loss of signal intensity is arguably caused by chemical exchange related to structural rearrangements induced by the $\mathrm{Li}^{+}$ions. As no chemical shift changes are observed for the crosspeak position (Fig. 3A), these $\mathrm{Li}^{+}$-induced secondary structures appear to be short-lived. Figure 3C and $3 \mathrm{D}$ show the results of similar experiments carried out in $1 \times$ PBS buffer, i.e. $137 \mathrm{mM} \mathrm{NaCl}, 2.7 \mathrm{mM} \mathrm{KCl}$, and $10 \mathrm{mM}$ phosphate $\mathrm{pH}$ 7.4. Here, the $\mathrm{Li}^{+}$ions induce virtually no changes in the crosspeak intensities, showing that the weak $\mathrm{Li}^{+} / \mathrm{A} \beta_{40}$ interactions observed in pure MES buffer (Figs. 3A, 3B) disappear when the buffer and ionic strength correspond to physiological conditions.

Diffusion measurements were carried out for $55 \mu \mathrm{M}$ $\mathrm{A} \beta_{40}$ peptides in $\mathrm{D}_{2} \mathrm{O}$, before and after addition of $\mathrm{LiCl}$ in $1: 1,20: 1$, and $100: 1 \mathrm{Li}^{+}: \mathrm{A} \beta$ ratios. Addition of $1: 1$ $\mathrm{Li}^{+}$produces an increase in the $A \beta_{40}$ diffusion rate by around $4 \%$, i.e. from $5.97 \cdot 10^{-11} \mathrm{~m}^{2} / \mathrm{s}$ to $6.23 \cdot 10^{-11} \mathrm{~m}^{2} / \mathrm{s}$ (Fig. 4A and 4B). This somewhat faster diffusion is likely caused by the $A \beta_{40}$ peptide adopting a slightly more compact structure in the presence of $\mathrm{Li}^{+}$ions, an effect similar to that previously reported for zinc ions (Abelein et al., 2015). Addition of even higher $\mathrm{Li}^{+}$concentrations 


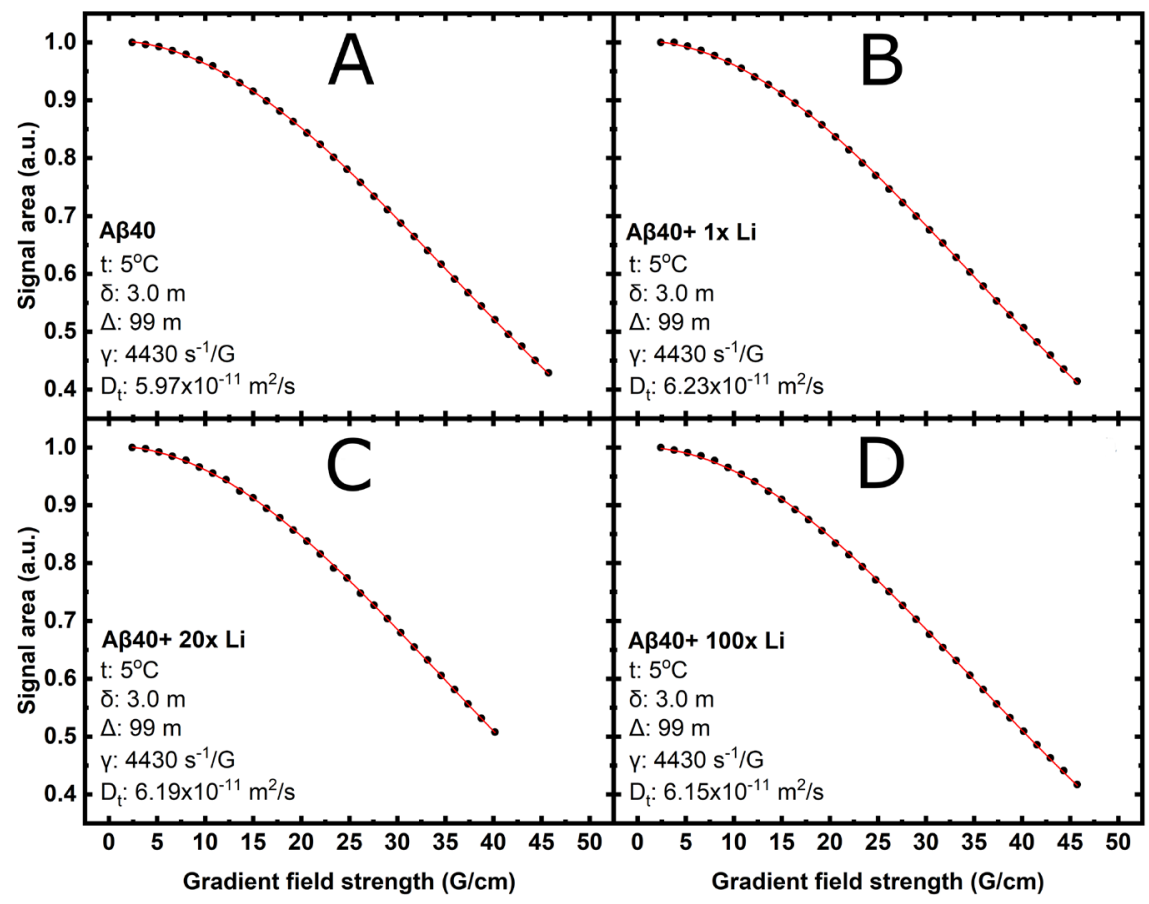

Figure 4. NMR diffusion data for $55 \mu \mathrm{M} \mathrm{A} \beta_{40}$ peptides in sodium phosphate buffer, pH 7.35 at $+5^{\circ} \mathrm{C}$, recorded both in absence $(\mathrm{A})$ and presence of different $\mathrm{Li}^{+}$concentrations, i.e. $55 \mu \mathrm{M}(\mathrm{B}), 1.1 \mathrm{mM}$ (C), and $5.5 \mathrm{mM}$ (D).

- 20 and 100 times the $A \beta_{40}$ concentration - produces diffusion rates that are similar but a little bit lower than the diffusion rate measured for $1: 1 \mathrm{Li}^{+}: \mathrm{A} \beta_{40}$ ratio, i.e. respectively $6.19 \cdot 10^{-11} \mathrm{~m}^{2} / \mathrm{s}$ and $6.15 \cdot 10^{-11} \mathrm{~m}^{2} / \mathrm{s}$ (Fig. 4C and 4D), indicating that the effect of $\mathrm{Li}^{+}$on the $A \beta_{40}$ secondary structure and diffusion has been saturated.

\section{Fluorescence spectroscopy: $\mathrm{Li}^{+}$binding affinity to the} $A \beta_{40}$ monomer

Binding affinities for metal ions to $A \beta$ peptides can often be measured via the quenching effect on the intrinsic fluorescence of Y10, the only fluorophore in native $A \beta$ peptides. However, not all metal ions interfere with tyrosine fluorescence, and initial experiments showed that addition of $\mathrm{Li}^{+}$ions does not affect the $\mathrm{A} \beta_{40}$ fluorescence. The binding affinity of $\mathrm{Li}^{+}$ions to $A \beta_{40}$ was therefore evalu-

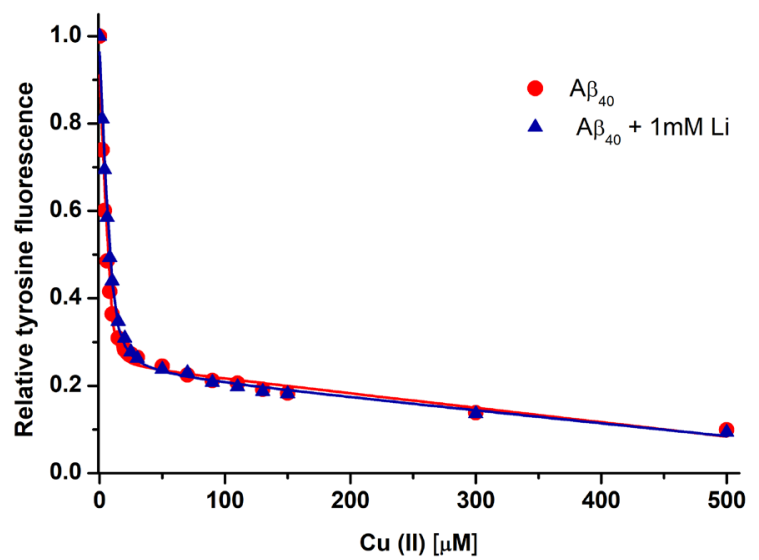

Figure 5. Binding curves for the $\mathrm{Cu}^{2+\cdot} \cdot \mathrm{A} \beta_{40}$ complex, obtained from the quenching effect of $\mathrm{Cu}^{2+}$ ions on the intrinsic fluorescence of $A \beta$ residue $Y 10$.

$\mathrm{CuCl}_{2}$ was titrated to $10 \mu \mathrm{M} \mathrm{A} \beta_{40}$ in $20 \mathrm{mM}$ MES buffer, $\mathrm{pH} 7.35$ at $20^{\circ} \mathrm{C}$, both in the absence (red dots) and the presence (blue triangles) of $1 \mathrm{mM} \mathrm{LiCl}$. ated from binding competition experiments with $\mathrm{Cu}^{2+}$ ions (Danielsson et al., 2007; Wallin et al., 2020), which induce much stronger tyrosine fluorescence quenching when bound to the peptide than when free in the solution (Lindgren et al., 2013). Figure 5 shows the results of titrating $\mathrm{CuCl}_{2}$ to $\mathrm{A} \beta_{40}$, both in the absence (red circles) and in the presence (blue triangles) of $1 \mathrm{mM} \mathrm{LiCl}$.

Three titrations were carried out for each condition, producing apparent $K_{D}$ values for the $\mathrm{Cu}^{2+} \cdot \mathrm{A} \beta_{40}$ complex of respectively $3.1 \mu \mathrm{M}, 2.1 \mu \mathrm{M}$, and $5.1 \mu \mathrm{M}$ without $\mathrm{LiCl}$, i.e. on average $3.4 \pm 1.6 \mu \mathrm{M}$, and $2.1 \mu \mathrm{M}, 0.9 \mu \mathrm{M}$, and $0.8 \mu \mathrm{M}$ with $\mathrm{LiCl}$ present, i.e. on average $1.3 \pm 0.8$ $\mu \mathrm{M}$. The obtained values are in line with earlier fluorescence measurements of the $\mathrm{Cu}^{2+}$ binding affinity to the $A \beta_{40}$ peptide, although this affinity is known to vary with the $\mathrm{pH}$, the buffer, and other experimental conditions (Ghalebani et al., 2012; Alies et al., 2013). The dif-

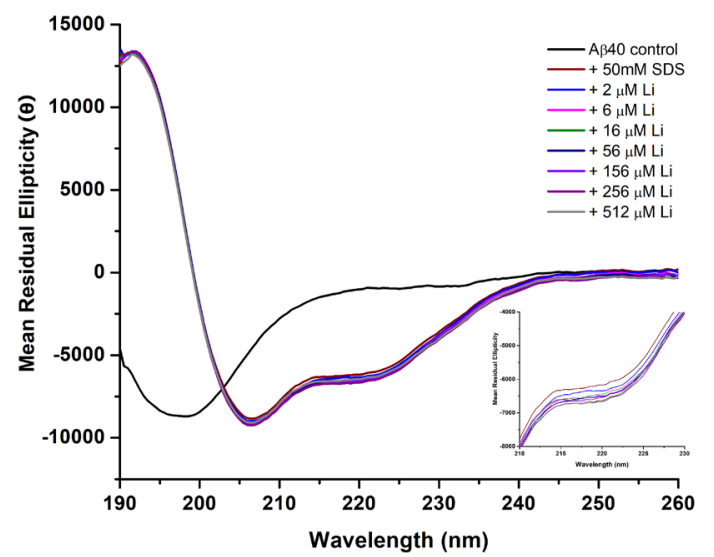

Figure 6. CD spectra of $20 \mu \mathrm{M} \mathrm{A} \beta_{40}$ peptides at $20^{\circ} \mathrm{C}$ in $20 \mathrm{mM}$ sodium phosphate buffer, $\mathrm{pH} 7.35$.

Spectra were recorded for $A \beta$ in buffer only (black), after addition of $50 \mathrm{mM}$ micellar SDS (brown), and after subsequent addition of between $2 \mu \mathrm{M}$ (blue) and $512 \mu \mathrm{M}$ (gray) of LiCl. The inset figure shows a close-up of the CD signals for the LiCl titration in the 210$230 \mathrm{~nm}$ range. 


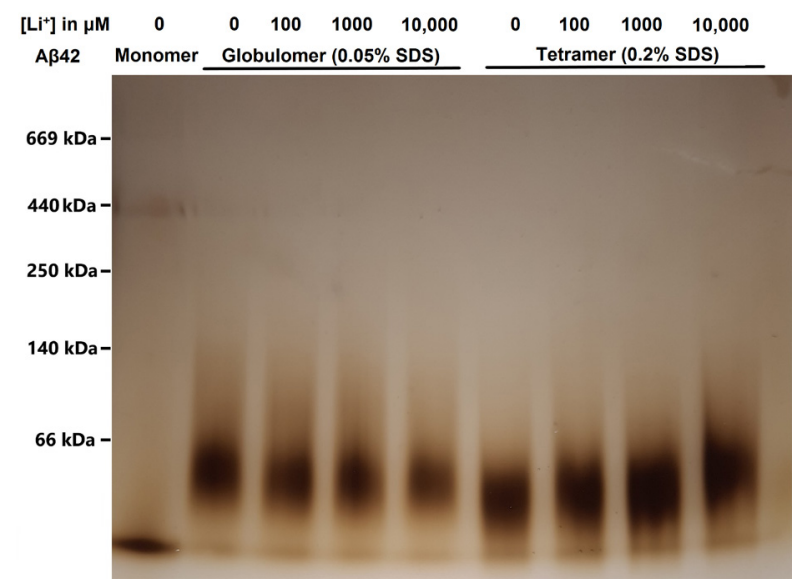

Figure 7. BN-PAGE gel showing the effects of different concentrations of $\mathrm{Li}^{+}$ions on the formation of SDS-stabilized $A \beta_{42}$ oligomers.

Lane 1: monomers prepared in $5 \mathrm{mM} \mathrm{NaOD}$. Lanes 2-5: $\mathrm{A} \beta$ globulomers formed after 24 hours of incubation with $0.05 \%$ SDS and different $\mathrm{LiCl}$ concentrations. Lanes 6-9: $A \beta_{42}$ oligomers formed after 24 hours of incubation with $0.2 \%$ SDS and different $\mathrm{LiCl}$ concentrations.

ference between the average measured $K_{D}$ values is not significant at the $5 \%$ level with a two-tailed $t$-test, which shows that $\mathrm{Li}^{+}$ions are not able to compete with $\mathrm{Cu}^{2+}$ for binding to $\mathrm{A} \beta$. Thus, the $\mathrm{Li}^{+}$binding affinity for $\mathrm{A} \beta_{40}$ is likely in the millimolar range, or weaker.

CD spectroscopy: effects of $\mathrm{Li}^{+}$ions on $A \beta_{40}$ structure in SDS

Although $A \beta$ peptides are generally disordered in aqueous solutions, they adopt an $\alpha$-helical secondary structure in membranes and membrane-mimicking environments such as SDS micelles (Tiiman et al., 2016; Osterlund et al., 2018). Thus, the $C D$ spectrum for $A \beta_{40}$ in sodium phosphate buffer displays the characteristic minimum for random coil structure at $198 \mathrm{~nm}$ (Fig. 6). Addition of $50 \mathrm{mM}$ SDS, which is well above the critical concentration for micelle formation (Österlund et al., 2018), induces an alpha-helical structure with characteristic minima around 208 and 222 $\mathrm{nm}$. Titrating $\mathrm{LiCl}$ in concentrations up to $512 \mu \mathrm{M}$ to the $\mathrm{A} \beta_{40}$ sample slightly increases the general CD intensity, but does not change the overall spectral shape - the minima remain at their respective positions. The intensity changes are not caused by dilution of the sample during the titration,

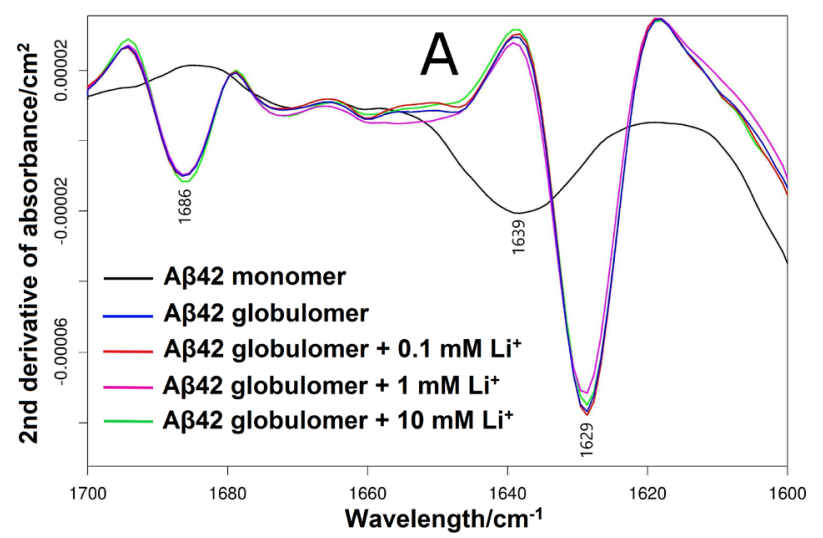

as the added volumes are very small, and as dilution would not increase but rather decrease the CD intensity. The observed changes in $\mathrm{CD}$ intensity therefore suggest a small but distinct binding effect of $\mathrm{LiCl}$ ions. This binding effect appears to be much weaker than the structural rearrangements and $A \beta$ coil-coil-interactions previously reported to be induced by $\mathrm{Cu}^{2+}$ ions (Tiiman et al., 2016).

\section{BN-PAGE: effects of $\mathrm{Li}^{+}$ions on $\mathrm{A} \beta_{42}$ oligomer formation and stability}

Well-defined and SDS-stabilized $A \beta_{42}$ oligomers were prepared in the presence of different amounts of $\mathrm{LiCl}$. SDS treatment of $\mathrm{A} \beta_{42}$ peptides at low concentrations $(\leq 7$ $\mathrm{mM}$ ) leads to formation of stable and homogeneous $A \beta_{42}$ oligomers of certain sizes and conformations (Barghorn et al., 2005; Rangachari et al., 2007). As shown in Fig. 7, two sizes of $A \beta_{42}$ oligomers are formed in presence of the two SDS concentrations. In $0.2 \%(6.9 \mathrm{mM})$ SDS, small oligomers with a molecular weight (MW) around 16-20 kDa are formed. These oligomers appear to contain a large fraction of tetramers (Vosough \& Barth, 2021). In 0.05\% (1.7 mM) SDS, larger oligomers with MWs around 55-60 $\mathrm{kD}$ are formed (Barghorn et al., 2005). These larger oligomers, which most likely contain twelve $A \beta_{42}$ monomers, display a globular morphology and are therefore sometimes called globulomers (Barghorn et al., 2005).

All oligomers were analyzed by BN-PAGE instead of by SDS-PAGE to avoid disruption by the high $(>1 \%)$ SDS concentrations used in SDS-PAGE (Bitan et al., 2005). As shown in lanes 2-5 and 6-9 of Fig. 7, increasing $\mathrm{LiCl}$ concentrations have weak or no effects on the size or homogeneity of the formed $A \beta_{42}$ oligomers, as the bands retain their shape and intensity. Only for the globulomers subjected to the highest $\mathrm{LiCl}$ concentration $(10 \mathrm{mM})$ is the intensity of the BN-PAGE band slightly reduced (lane 5, Fig 7).

\section{FTIR spectroscopy: effects of $\mathrm{Li}^{+}$ions on $\mathrm{A} \beta_{42}$ oligomer structure}

The secondary structures of $A \beta_{42}$ oligomers formed with different $\mathrm{Li}^{+}$concentrations were studied with FTIR spectroscopy, where the amide I region $\left(1700-1600 \mathrm{~cm}^{-1}\right)$ is very sensitive to changes in the protein backbone conformation. The technique is useful also in amyloid research, given its capacity to characterize $\beta$-sheets (Barth, 2007; Sarroukh et al., 2013).

Figure 8 shows second derivative IR spectra for the amide I region of $A \beta_{42}$ globulomers (Fig. 8A) and smaller oligomers (Fig. 8B), prepared with different concentrations

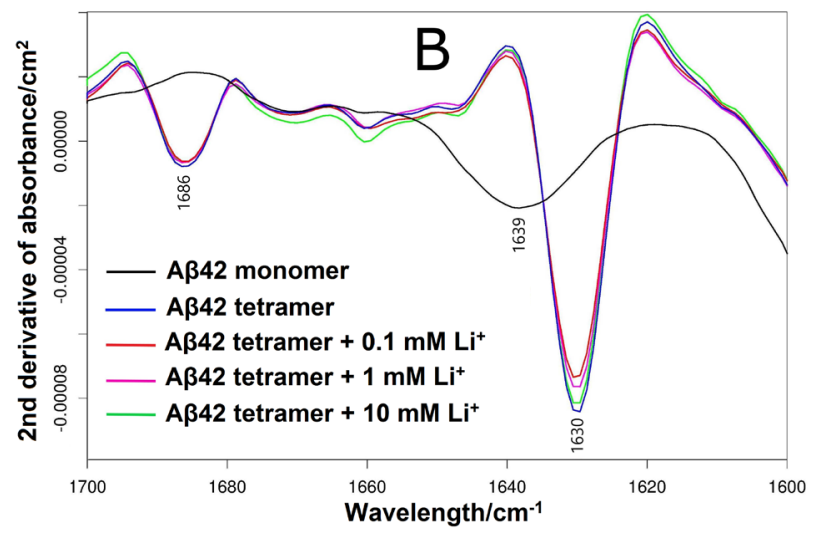

Figure 8. Second derivatives of infrared absorbance spectra for $100 \mu \mathrm{MA} \beta_{42}$ monomers (black) and $80 \mu \mathrm{M}$ SDS-stabilized $A \beta_{42}$ oligomers formed in absence (blue) and presence of $0.1 \mathrm{mM}$ (red), $1 \mathrm{mM}$ (purple), and $10 \mathrm{mM}$ (green) of LiCl. The results are shown for $A \beta_{42}$ globulomers at $0.05 \%$ SDS (A) and smaller oligomers at $0.2 \%$ SDS (B). 
of $\mathrm{Li}^{+}$ions. Monomeric $\mathrm{A} \beta_{42}$ displayed a relatively broad band at $1639-1640 \mathrm{~cm}^{-1}$, which is in agreement with the position of the band for disordered (random coil) polypeptides measured in $\mathrm{D}_{2} \mathrm{O}$ (Barth, 2007). For both types of $\mathrm{A} \beta_{42}$ oligomers, this main band is much narrower and downshifted by about $10 \mathrm{~cm}^{-1}$, while a second smaller band appears around $1685 \mathrm{~cm}^{-1}$. This split band pattern is indicative of an anti-parallel $\beta$-sheet conformation (Barth, 2007; Cerf et al., 2009; Sarroukh et al., 2013). Earlier studies in our laboratory have shown a relationship between the position and width of this main band, and the size and homogeneity of the $A \beta_{42}$ oligomers (Vosough \& Barth, 2021). The lower band position of the larger oligomers is in line with this relationship and our previous results, and confirms the different sizes of the oligomers produced at the two SDS concentrations. We have recently observed that a number of transition metal ions induce significant effects on the main band position for $A \beta_{42}$ oligomers (Vosough \& Barth, 2021). Because the spectra for $A \beta_{42}$ oligomers formed with different amounts of $\mathrm{LiCl}$ generally superimpose on the IR spectra for the $\mathrm{Li}^{+}$-free oligomers, with no shifts observed for the main band, it appears that $\mathrm{Li}^{+}$ions have no significant effect on the oligomers' size or secondary structure.

\section{DISCUSSION}

\section{Lithium as a therapeutic agent}

Lithium has no known biological functions in the human body. $\mathrm{Li}^{+}$ions readily pass biological membranes, and are evenly distributed in tissues and easily eliminated via the kidneys (Nordberg et al., 2015). $\mathrm{Li}^{+}$ions are however far from inert, and several well-defined medical conditions related to abnormal $\mathrm{Li}^{+}$concentrations exist. In low blood concentrations, $\mathrm{Li}^{+}$is used as a medication for bipolar and schizoaffective disorders (Machado-Vieira et al., 2009), but at higher concentrations $\mathrm{Li}^{+}$ions are neurotoxic (Sellers et al., 1982; Emilien \& Maloteaux, 1996; Nordberg et al., 2015; Wen et al., 2019). This leaves a narrow therapeutic window of $0.6-1.2 \mathrm{mM}$ that has to be closely monitored in order to prevent $\mathrm{Li}^{+}$intoxication, which is easily recognized by EEG (Electroencephalography) (Mignarri et al., 2013) and treatable by reducing the therapeutic dose. $\mathrm{Li}^{+}$intoxication $(>1.5 \mathrm{mM})$ presents as apathy, vertigo, tremor and gastrointestinal symptoms, in more severe cases confusion, psychosis, myoclonus and cardiac arrhythmias (Nordberg et al., 2015). $\mathrm{Li}^{+}$intoxication affects also the kidneys with polyuria and elevated $\mathrm{U}$-albumin although overt renal failure is rare (Nordberg et al., 2015).

Treatment of bipolar and schizoaffective disorders with $\mathrm{Li}^{+}$has generated some knowledge about $\mathrm{Li}^{+}$metabolism in the human body (Wen et al., 2019; Medic et al., 2020). $\mathrm{Li}^{+}$accumulates to some extent in bone (Birch, 1974), and chronic $\mathrm{Li}^{+}$effects are implicated in osteomalacia and severe osteoporosis (Roos, 2014). Patients treated with $\mathrm{Li}^{+}$also show an increased frequency of hypothyroidism and goitre, and widespread effects on several facets of the endocrine system have been noted (Salata \& Klein, 1987). The negative effects of $\mathrm{Li}^{+}$on thyroid function have been clearly demonstrated in a study on populations in the Andean Mountains, where natural exposure to $\mathrm{Li}^{+}$is high, and where urinary $\mathrm{Li}^{+}$ was found to correlate negatively with free thyroxine $\left(\mathrm{T}_{4}\right)$ but correlate positively with the pituitary gland hormone thyrotropin (Broberg et al., 2011). The toxicity of $\mathrm{Li}^{+}$is further emphasized by studies from regions with naturally elevated concentrations of $\mathrm{Li}^{+}$in potable wa- ter, where reduced fetal size has been noted to correlate linearly with increases in blood $\mathrm{Li}^{+}$(Harari et al., 2015).

To what extent $\mathrm{Li}^{+}$treatment reduces the development of AD symptoms is unclear (Engel et al., 2008; Mauer et al., 2014; Nordberg et al., 2015; Sutherland \& Duthie, 2015). Bipolar disorder increases the risk of AD when compared to the general population, and $\mathrm{Li}^{+}$treatment seems to reduce this risk (Velosa et al., 2020), but the mechanisms mediating this effect are far from elucidated (Kerr et al., 2018). In rare cases even regular-dose longtime $\mathrm{Li}^{+}$therapy may cause severe intoxication of the central nervous system, characterized by cerebellar dysfunction and cognitive decline (Emilien \& Maloteaux, 1996).

\section{Lithium interactions with the $A \beta_{40}$ peptide}

The NMR (Figs. 3 and 4), fluorescence quenching (Fig. 5), and $\mathrm{CD}$ (Fig. 6) experiments show that $\mathrm{Li}^{+}$ions display weak interaction with the $A \beta_{40}$ peptide, where the binding affinity for the $\mathrm{Li}^{+} \cdot \mathrm{A} \beta_{40}$ complex may be in the millimolar range. The IR and CD results show minor or no effects of $\mathrm{Li}^{+}$ions on the secondary structures of $\mathrm{A} \beta_{40}$ monomers (Fig. 6) and $A \beta_{42}$ oligomers (Fig. 8). The $\mathrm{Li}^{+}$ions may have a small effect on $A \beta$ aggregation, with minor perturbations on the morphology of aggregated $A \beta_{40}$ fibrils (Fig. 2), and effects on the $A \beta_{40}$ aggregation kinetics (Fig. 1; Table 1) and $A \beta_{42}$ oligomer stability (Fig. 7) only at very high $\mathrm{Li}^{+}$ concentrations. These results are in line with previous computer modeling results, which suggest small differences between how the monovalent $\mathrm{K}^{+}, \mathrm{Li}^{+}$, and $\mathrm{Na}^{+}$alkali ions affect $A \beta$ oligomerization (Huraskin \& Horn, 2019).

As $A \beta_{40}$ and $A \beta_{42}$ have identical N-terminal sequences, the two peptide variants should interact very similarly with $\mathrm{Li}^{+}$ions, which were found to bind to the N-terminal A $\beta$ region (Fig. 3B). The weak affinity between $\mathrm{A} \beta_{40}$ and $\mathrm{Li}^{+}$ ions, and the fact that $\mathrm{Li}^{+}$does not efficiently compete with $\mathrm{Cu}^{2+}$ ions for $\mathrm{A} \beta$ binding (Fig. 4), suggest that $\mathrm{Li}^{+}$ ions are not coordinated by specific binding ligands. Instead, $\mathrm{Li}^{+}$likely engages in non-specific electrostatic interactions with the negatively charged $A \beta$ residues, i.e. D1, E3, D7, E11, E22, and D23 (which are located in the Nterminal and central regions).

The weak binding affinity to $A \beta_{40}$ peptides is not caused by $\mathrm{Li}^{+}$ions being monovalent, as e.g. monovalent $\mathrm{Ag}^{+}$ions display rather strong and specific binding to $\mathrm{A} \beta$ peptides (Wallin et al., 2020). Moreover, divalent $\mathrm{Pb}^{2+}$ and trivalent $\mathrm{Cr}^{3+}$ ions do not bind strongly to $\mathrm{A} \beta$, while divalent $\mathrm{Cu}^{2+}, \mathrm{Mn}^{2+}$ and $\mathrm{Zn}^{2+}$ as well as tetravalent $\mathrm{Pb}^{4+}$ ions do (Faller, 2009; Abelein et al., 2015; Tiiman et al., 2016; Wallin et al., 2016; Wallin et al., 2017). Thus, A $\beta$ / metal interactions are not governed by the charge of the metal ion, but rather by its specific properties, such as ionic radius and electron configuration $\left(1 \mathrm{~s}^{2}\right.$ for $\left.\mathrm{Li}^{+}\right)$.

It is illustrative to compare the $A \beta$ interactions with $\mathrm{Li}^{+}$ ions to the well-studied interactions with $\mathrm{Cu}^{2+}$ and $\mathrm{Zn}^{2+}$ ions. These two divalent ions display residue-specific interactions with $A \beta$ peptides, displaying binding affinities in the micromolar-nanomolar range and strong effects on $A \beta$ secondary structure, aggregation, and diffusion (Danielsson et al., 2007; Faller, 2009; Lindgren et al., 2013; Abelein et al., 2015; Tiiman et al., 2016; Owen et al., 2019). A $\beta$ binding to $\mathrm{Cu}^{2+}$ and $\mathrm{Zn}^{2+}$ is coordinated mainly by residue-specific interactions with the $\mathrm{N}$-terminal His residues, i.e. H6, H13, and H14 (Faller, 2009; Lindgren et al., 2013; Abelein et al., 2015; Tiiman et al., 2016). The biological relevance of $\mathrm{Cu}^{2+}$ and $\mathrm{Zn}^{2+}$ ions in $\mathrm{AD}$ pathology is demonstrated by their dysregulation in AD patients (Wang et al., 2015; Szabo et al., 2016), and by them being accumulated in plaques of $A \beta$ aggregates in AD brains (Beauchemin \& Kisilevsky, 1998; 
Lovell et al., 1998; Miller et al., 2006). During neuronal signaling $\mathrm{Cu}^{2+}$ and $\mathrm{Zn}^{2+}$ ions are released into the synaptic clefts (Ayton et al., 2013), where they may interact with A $\beta$ peptides to initiate $A \beta$ aggregation (Branch et al., 2017), or modulate the formation and toxicity of $A \beta$ oligomers (Stefaniak \& Bal, 2019; Wärmländer et al., 2019).

The current results indicate that $\mathrm{Li}^{+}$ions are not able to compete with $\mathrm{Cu}^{2+}$ or $\mathrm{Zn}^{2+}$ ions for binding to $\mathrm{A} \beta$ peptides, and should therefore not be able to influence the in vivo effects of $\mathrm{Cu}^{2+}$ and $\mathrm{Zn}^{2+}$ ions on $\mathrm{A} \beta$ aggregation and toxicity. Although high concentrations of $\mathrm{Li}^{+}$showed some effects on $A \beta$ aggregation (Figs. 1-3; 7), these effects are likely at least partly related to ionic strength effects (Abelein et al., 2016). Under physiological ionic strength, no specific interactions are observed between $\mathrm{A} \beta_{40}$ monomers and $\mathrm{Li}^{+}$ ions (Fig. 3C, 3D). Thus, we conclude that the previously reported possible beneficial effects of $\mathrm{Li}^{+}$on Alzheimer's disease progression (Mauer et al., 2014; Sutherland \& Duthie, 2015; Kerr et al., 2018; Hampel et al., 2019; Velosa et al., 2020) seem not to be caused by direct interactions between $\mathrm{Li}^{+}$ions and $A \beta$ peptides.

\section{Acknowledgments}

We thank Elizabeth (Li) Wang for helpful discussions.

\section{Conflict of Interest}

The authors declare no conflict of interest.

\section{REFERENCES}

Abelein A, Abrahams JP, Danielsson J, Gräslund A, Jarvet J, Luo J, Tiiman A, Wärmländer SK (2014) The hairpin conformation of the amyloid beta peptide is an important structural motif along the aggregation pathway. J Biol Inorg Chem 19: 623-634. https://doi. org/10.1007/s00775-014-1131-8

Abelein A, Gräslund A, Danielsson J (2015) Zinc as chaperone-mimicking agent for retardation of amyloid beta peptide fibril formation. Proc Natl Acad Sci U S A 112: 5407-5412. https://doi.org/10.1073/ pnas.1421961112

Abelein A, Jarvet J, Barth A, Gräslund A, Danielsson J (2016) Ionic strength modulation of the free energy landscape of abeta40 peptide fibril formation. I Am Chem Soc 138: 6893-6902. https://doi. org $/ 10.1021 /$ jacs.6b04511

Adlard PA, Bush AI (2018) Metals and Alzheimer's disease: how far have we come in the clinic? I Alsheimers Dis 62: 1369-1379. https://doi.org/10.3233/JAD-170662

Agostinho P, Cunha RA, Oliveira C (2010) Neuroinflammation, oxidative stress and the pathogenesis of Alzheimer's disease. Curr Pharm Des 16: 2766-2778. https://doi.org/10.2174/138161210793176572

Al-Hilaly YK, Williams TL, Stewart-Parker M, Ford L, Skaria E, Cole M, Bucher WG, Morris KL, Sada AA, Thorpe JR, Serpell LC (2013) A central role for dityrosine crosslinking of Amyloid-beta in Alzheimer's disease. Acta Neuropathol Commun 1: 83. https://doi, org/10.1186/2051-5960-1-83

Alies B, Renaglia E, Rozga M, Bal W, Faller P, Hureau C (2013) Cu(II) affinity for the Alzheimer's peptide: tyrosine fluorescence studies revisited. Anal Chem 85: 1501-1508. https://doi.org/10.1021/ ac302629u

Ayton S, Lei P, Bush AI (2013) Metallostasis in Alzheimer's disease. Free Radic Biol Med 62: 76-89. https://doi.org/10.1016/j.freeradbiomed.2012.10.558

Baldassarre M, Barth A (2014) Pushing the detection limit of infrared spectroscopy for structural analysis of dilute protein samples. Analyst 139: 5393-5399. https://doi.org/10.1039/c4an00918e

Barghorn S, Nimmrich V, Striebinger A, Krantz C, P K, Janson B, Bahr M, Schmidt M, Bitner RS, Harlan J, Barlow E, Ebert U, Hillen H (2005) Globular amyloid $\beta$-peptide1-42 oligomer - a homogenous and stable neuropathological protein in Alzheimer's disease. J Neurochem 95: 834-847. https://doi.org/10.1111/j.14714159.2005.03407.x

Baronio CM, Baldassarre M, Barth A (2019) Insight into the internal structure of amyloid-beta oligomers by isotope-edited Fourier transform infrared spectroscopy. Phys Chem Chem Phys 21: 8587-8597. https://doi.org/10.1039/c9cp00717b

Barth A (2007) Infrared spectroscopy of proteins. Biochim Biophys Acta 1767: 1073-1101. https://doi.org/10.1016/j.bbabio.2007.06.004
Beauchemin D, Kisilevsky R (1998) A method based on ICP-MS for the analysis of Alzheimer's amyloid plaques. Anal Chem 70: 10261029. https://doi.org/10.1021/ac970783f

Birch NJ (1974) Lithium accumulation in bone after oral administration in rat and in man. Clin Sci Mol Med 46: 409-413. https://doi. org/10.1042/cs0460409

Bitan G, Fradinger EA, Spring SM, Teplow DB (2005) Neurotoxic protein oligomers - what you see is not always what you get. Amyloid 12: 88-95. https://doi.org/10.1080/13506120500106958

Branch T, Barahona M, Dodson CA, Ying L (2017) Kinetic analysis reveals the identity of abeta-metal complex responsible for the initial aggregation of abeta in the synapse. ACS Chem Neurosci 8: 1970 1979. https://doi.org/10.1021/acschemneuro.7b00121

Broberg K, Concha G, Engstrom K, Lindvall M, Grander M, Vahter M (2011) Lithium in drinking water and thyroid function. Environ Health Perspect 119: 827-830. https://doi.org/10.1289/ehp.1002678

Budni J, Feijo DP, Batista-Silva H, Garcez ML, Mina F, BelletiniSantos T, Krasilchik LR, Luz AP, Schiavo GL, Quevedo J (2017) Lithium and memantine improve spatial memory impairment and neuroinflammation induced by beta-amyloid 1-42 oligomers in rats. Neurobiol Learn Mem 141: 84-92. https://doi.org/10.1016/j. nlm.2017.03.017

Caccamo A, Oddo S, Tran LX, LaFerla FM (2007) Lithium reduces tau phosphorylation but not A beta or working memory deficits in a transgenic model with both plaques and tangles. Am J Pathol 170: 1669-1675. https://doi.org/10.2353/ajpath.2007.061178

Cardillo GM, De-Paula VJR, Ikenaga EH, Costa LR, Catanozi S, Schaeffer EL, Gattaz WF, Kerr DS, Forlenza OV (2018) Chronic lithium treatment increases telomere length in parietal cortex and hippocampus of triple-transgenic Alzheimer's disease mice. J Alqheimers Dis 63: 93-101. https://doi.org/10.3233/JAD-170838

Cerf E, Sarroukh R, Tamamizu-Kato S, Breydo L, Derclaye S, Dufrene YF, Narayanaswami V, Goormaghtigh E, Ruysschaert JM, Raussens V (2009) Antiparallel beta-sheet: a signature structure of the oligomeric amyloid beta-peptide. Biochem J 421: 415-423. https://doi. org/10.1042/BJ20090379

Chin-Chan M, Navarro-Yepes J, Quintanilla-Vega B (2015) Environmental pollutants as risk factors for neurodegenerative disorders: Alzheimer and Parkinson diseases. Front Cell Neurosci 9: 124. https://doi.org/10.3389/fncel.2015.00124

Cho CH, Urquidi J, Singh S, Wilse Robinson G (1999) Thermal offset viscosities of liquid $\mathrm{H}_{2} \mathrm{O}, \mathrm{D}_{2} \mathrm{O}$, and $\mathrm{T}_{2} \mathrm{O}$. J Phys Chem B 103: 1991-1994. https://doi.org/10.1021/jp9842953

Danielsson J, Andersson A, Jarvet J, Gräslund A (2006) $15 \mathrm{~N}$ relaxation study of the amyloid beta-peptide: structural propensities and persistence length. Magn Reson Chem 44 Spec No: S114-S121. https://doi. org/10.1002/mrc.1814

Danielsson J, Jarvet J, Damberg P, Gräslund A (2002) Translational diffusion measured by PFG-NMR on full length and fragments of the Alzheimer $A \beta(1-40)$ peptide. Determination of hydrodynamic radii of random coil peptides of varying length. Magnet Res Chem 40: S89-S97. https://doi.org/10.1002/mrc.1132

Danielsson J, Pierattelli R, Banci L, Gräslund A (2007) High-resolution NMR studies of the zinc-binding site of the Alzheimer's amyloid beta-peptide. FEBS J 274: 46-59. https://doi.org/10.1111/j.17424658.2006.05563.x

Decker M, Munoz-Torrero D (2016) Special Issue: "Molecules against Alzheimer". Molecules 21. https://doi.org/10.3390/molecules21121736

Dell'Osso L, Del Grande C, Gesi C, Carmassi C, Musetti L (2016) A new look at an old drug: neuroprotective effects and therapeutic potentials of lithium salts. Neuropsychiatr Dis Treat 12: 1687-1703. https://doi.org/10.2147/NDT.S106479

Donix M, Bauer M (2016) Population Studies of Association Between Lithium and Risk of Neurodegenerative Disorders. Curr Alzheimer Res 13: 873-878. https://doi.org/10.2174/156720501366616021911 2957

Duce JA, Bush AI, Adlard PA (2011) Role of amyloid- $\beta-$ metal interactions in Alzheimer's disease. Future Neurol 6: 641-659. https://doi. org $/ 10.2217 /$ fnl.11.43

Edelhoch H (1967) Spectroscopic determination of tryptophan and tyrosine in proteins. Biochemistry 6: 1948-1954. https://doi. org/10.1021/bi00859a010

Emilien G, Maloteaux JM (1996) Lithium neurotoxicity at low therapeutic doses Hypotheses for causes and mechanism of action following a retrospective analysis of published case reports. Acta Neurol Belg 96: 281-293. PMID: 9008777

Engel T, Goni-Oliver P, Gomez de Barreda E, Lucas JJ, Hernandez F, Avila J (2008) Lithium, a potential protective drug in Alzheimer's disease. Neurodegener Dis 5: 247-249. https://doi. org $/ 10.1159 / 000113715$

Faller P (2009) Copper and zinc binding to amyloid-beta: coordination, dynamics, aggregation, reactivity and metal-ion transfer. Chembiochem 10: 2837-2845. https://doi.org/10.1002/cbic.200900321

Forlenza OV, De-Paula VJ, Diniz BS (2014) Neuroprotective effects of lithium: implications for the treatment of Alzheimer's disease and 
related neurodegenerative disorders. ACS Chem Neurosici 5: 443-450. https://doi.org/10.1021/cn5000309

Fornai F, Longone P, Cafaro L, Kastsiuchenka O, Ferrucci M, Manca ML, Lazzeri G, Spalloni A, Bellio N, Lenzi P, Modugno N, Siciliano G, Isidoro C, Murri L, Ruggieri S, Paparelli A (2008) Lithium delays progression of amyotrophic lateral sclerosis. Proc Natl Acad Sci US A 105: 2052-2057. https://doi.org/10.1073/pnas.0708022105

Frozza RL, Lourenco MV, De Felice FG (2018) Challenges for alzheimer's disease therapy: insights from novel mechanisms beyond memory defects. Front Neurosci 12: 37. https://doi.org/10.3389/ fnins.2018.00037

Gade Malmos K, Blancas-Mejia LM, Weber B, Buchner J, Ramirez-Alvarado M, Naiki H, Otzen D (2017) ThT 101: a primer on the use of thioflavin $\mathrm{T}$ to investigate amyloid formation. Amyloid 24: 1-16. https://doi.org/10.1080/13506129.2017.1304905

Ge W, Jakobsson E (2018) Systems biology understanding of the effects of lithium on affective and neurodegenerative disorders. Front Neurosci 12: 933. https://doi.org/10.3389/fnins.2018.00933

Ghalebani L, Wahlström A, Danielsson J, Wärmländer SK, Gräslund A (2012) pH-dependence of the specific binding of $\mathrm{Cu}$ (II) and $\mathrm{Zn}$ (II) ions to the amyloid-beta peptide. Biochem Biophys Res Commun 421: 554-560. https://doi.org/10.1016/j.bbrc.2012.04.043

Gibbons GS, Lee VMY, Trojanowski JQ (2019) Mechanisms of cellto-cell transmission of pathological tau: a review. JAMA Neurol 76: 101-108. https://doi.org/10.1001/jamaneurol.2018.2505

Glasoe PK, Long FA (1960) Use of glass electrodes to measure acidities in deuterium oxide. J Phys Chem 64: 88-90. https://doi. org/10.1021/j100830a521

Glenner GG, Wong CW (1984) Alzheimer's disease: initial report of the purification and characterization of a novel cerebrovascular amyloid protein. Biochem Biophys Res Commun 120: 885-890. https://doi. org/10.1016/s0006-291x(84)80190-4

Goedert M (2018) Tau filaments in neurodegenerative diseases. FEBS Lett 592: 2383-2391. https://doi.org/10.1002/1873-3468.13108

Habib A, Sawmiller D, Li S, Xiang Y, Rongo D, Tian J, Hou H, Zeng J, Smith A, Fan S, Giunta B, Mori T, Currier G, Shytle DR, Tan J (2017) LISPRO mitigates beta-amyloid and associated pathologies in Alzheimer's mice. Cell Death Dis 8: e2880. https://doi.org/10.1038/ cddis.2017.279

Habib A, Shytle RD, Sawmiller D, Koilraj S, Munna SA, Rongo D, Hou H, Borlongan CV, Currier G, Tan J (2019) Comparing the effect of the novel ionic cocrystal of lithium salicylate proline (LISPRO) with lithium carbonate and lithium salicylate on memory and behavior in female APPswe/PS1dE9 Alzheimer's mice. I Neurosci Res 97: 1066-1080. https://doi.org/10.1002/jnr.24438

Hampel H, Lista S, Mango D, Nistico R, Perry G, Avila J, Hernandez F, Geerts H, Vergallo A, Alzheimer Precision Medicine I (2019) Lithium as a treatment for Alzheimer's disease: the systems pharmacology perspective. I Alzheimers Dis 69: 615-629. https://doi. org/10.3233/JAD-190197

Harari F, Langeen M, Casimiro E, Bottai M, Palm B, Nordqvist H, Vahter M (2015) Environmental exposure to lithium during pregnancy and fetal size: a longitudinal study in the Argentinean Andes. Environ Int 77: 48-54. https://doi.org/10.1016/j.envint.2015.01.011

Heppner FL, Ransohoff RM, Becher B (2015) Immune attack: the role of inflammation in Alzheimer disease. Nat Rev Neurosci 16: 358-372. https://doi.org/10.1038/nrn3880

Huat TJ, Camats-Perna J, Newcombe EA, Valmas N, Kitazawa M, Medeiros R (2019) Metal toxicity links to Alzheimer's disease and neuroinflammation. J Mol Biol 431: 1843-1868. https://doi. org/10.1016/j.jmb.2019.01.018

Huraskin D, Horn AHC (2019) Alkali ion influence on structure and stability of fibrillar amyloid-beta oligomers. J Mol Model 25: 37. https://doi.org/10.1007/s00894-018-3920-4

Kerr F, Bjedov I, Sofola-Adesakin O (2018) Molecular mechanisms of lithium action: switching the light on multiple targets for dementia using animal models. Front Mol Neurosci 11: 297. https://doi. org/10.3389/fnmol.2018.00297

Kisby B, Jarrell JT, Agar ME, Cohen DS, Rosin ER, Cahill CM, Rogers JT, Huang X (2019) Alzheimer's disease and its potential alternative therapeutics. J Alzheimers Dis Parkinsonism 9. https://doi. org/10.4172/2161-0460.1000477

Lee SJ, Nam E, Lee HJ, Savelieff MG, Lim MH (2017) Towards an understanding of amyloid-beta oligomers: characterization, toxicity mechanisms, and inhibitors. Chem Soc Rev 46: 310-323. https://doi. org/10.1039/c6cs00731g

Lindgren J, Segerfeldt P, Sholts SB, Gräslund A, Karlström AE, Wärmländer SK (2013) Engineered non-fluorescent Affibody molecules facilitate studies of the amyloid-beta (Abeta) peptide in monomeric form: low $\mathrm{pH}$ was found to reduce Abeta/Cu(II) binding affinity. J Inorg Biochem 120: 18-23. https://doi.org/10.1016/j.jinorgbio.2012.11.005

Liu M, Qian T, Zhou W, Tao X, Sang S, Zhao L (2020) Beneficial effects of low-dose lithium on cognitive ability and pathological alteration of Alzheimer's disease transgenic mice model. Neuroreport 31: 943-951. https://doi.org/10.1097/WNR.0000000000001499
Lovell MA, Robertson JD, Teesdale WJ, Campbell JL, Markesbery WR (1998) Copper, iron and zinc in Alzheimer's disease senile plaques. J Neurol Sci 158: 47-52. https://doi.org/10.1016/s0022$510 \times(98) 00092-6$

Luo J, Mohammed I, Wärmländer SK, Hiruma Y, Gräslund A, Abrahams JP (2014) Endogenous polyamines reduce the toxicity of soluble abeta peptide aggregates associated with Alzheimer's disease. Biomacromolecules 15: 1985-1991. https://doi.org/10.1021/bm401874j

Luo J, Otero JM, Yu CH, Wärmländer SK, Gräslund A, Overhand M, Abrahams JP (2013) Inhibiting and reversing amyloid-beta peptide (1-40) fibril formation with gramicidin $S$ and engineered analogues. Chemistry 19: 17338-17348. https://doi.org/10.1002/ chem.201301535

Luo J, Wärmländer SK, Gräslund A, Abrahams JP (2014) Alzheimer peptides aggregate into transient nanoglobules that nucleate fibrils. Biochemistry 53: 6302-6308. https://doi.org/10.1021/bi5003579

Luo J, Wärmländer SK, Gräslund A, Abrahams JP (2016) Cross-interactions between the Alzheimer Disease amyloid-beta peptide and other amyloid proteins: a further aspect of the amyloid cascade hypothesis. J Biol Chem 291: 16485-16493. https://doi.org/10.1074/ jbc.R116.714576

Luo J, Yu CH, Yu H, Borstnar R, Kamerlin SC, Gräslund A, Abrahams JP, Wärmländer SK (2013) Cellular polyamines promote amyloid-beta (Abeta) peptide fibrillation and modulate the aggregation pathways. ACS Chem Neurosci 4: 454-462. https://doi.org/10.1021/ cn300170x

Machado-Vieira R, Manji HK, Zarate CA, Jr. (2009) The role of lithium in the treatment of bipolar disorder: convergent evidence for neurotrophic effects as a unifying hypothesis. Bipolar Disord 11 (Suppl 2): 92-109. https://doi.org/10.1111/j.1399-5618.2009.00714.x

Mauer S, Vergne D, Ghaemi SN (2014) Standard and trace-dose lithium: a systematic review of dementia prevention and other behavioral benefits. Aust N Z J Psychiatry 48: 809-818. https://doi. org/10.1177/0004867414536932

Medic B, Stojanovic M, Stimec BV, Divac N, Vujovic KS, Stojanovic R, Colovic M, Krstic D, Prostran M (2020) Lithium - pharmacological and toxicological aspects: the current state of the art. Curr Med Chem 27: 337-351. https://doi.org/10.2174/092986732566618 0904124733

Mignarri A, Chini E, Rufa A, Rocchi R, Federico A, Dotti MT (2013) Lithium neurotoxicity mimicking rapidly progressive dementia. J Neurol 260: 1152-1154. https://doi.org/10.1007/s00415-012-6820-z

Miller LM, Wang Q, Telivala TP, Smith RJ, Lanzirotti A, Miklossy J (2006) Synchrotron-based infrared and X-ray imaging shows focalized accumulation of $\mathrm{Cu}$ and $\mathrm{Zn}$ co-localized with beta-amyloid deposits in Alzheimer's disease. I Struct Biol 155: 30-37. https://doi. org/10.1016/j.jsb.2005.09.004

Mital M, Wezynfeld NE, Fraczyk T, Wiloch MZ, Wawrzyniak UE, Bonna A, Tumpach C, Barnham KJ, Haigh CL, Bal W, Drew SC (2015) A functional role for abeta in metal homeostasis? n-truncation and high-affinity copper binding. Angew Chem Int Ed Engl 54: 10460-10464. https://doi.org/10.1002/anie.201502644

Modgil S, Lahiri DK, Sharma VL, Anand A (2014) Role of early life exposure and environment on neurodegeneration: implications on brain disorders. Transl Neurodegener 3: 9. https://doi. org/10.1186/2047-9158-3-9

Morris G, Berk M (2016) The putative use of lithium in Alzheimer's Disease. Curr Alzhbeimer Res 13: 853-861. https://doi.org/10.2174/15 67205013666160219113112

Morrison KE, Dhariwal S, Hornabrook R, Savage L, Burn DJ, Khoo TK, Kelly J, Murphy CL, Al-Chalabi A, Dougherty A, Leigh PN, Wijesekera L, Thornhill M, Ellis CM, O'Hanlon K, Panicker J, Pate L, Ray P, Wyatt L, Young CA, Copeland L, Ealing I, Hamdalla H, Leroi I, Murphy C, O’Keeffe F, Oughton E, Partington L, Paterson P, Rog D, Sathish A, Sexton D, Smith J, Vanek H, Dodds S, Williams TL, Steen IN, Clarke J, Eziefula C, Howard R, Orrell R, Sidle K, Sylvester R, Barrett W, Merritt C, Talbot K, Turner MR, Whatley C, Williams C, Williams J, Cosby C, Hanemann CO, Iman I, Philips C, Timings L, Crawford SE, Hewamadduma C, Hibberd R, Hollinger H, McDermott C, Mils G, Rafig M, Shaw PJ, Taylor A, Waines E, Walsh T, Addison-Jones R, Birt J, Hare M, Majid T (2013) Lithium in patients with amyotrophic lateral sclerosis (LiCALS): a phase 3 multicentre, randomised, double-blind, placebocontrolled trial. Lancet Neurol 12: 339-345. https://doi.org/10.1016/ S1474-4422(13)70037-1

Nath S, Agholme L, Kurudenkandy FR, Granseth B, Marcusson J, Hallbeck M (2012) Spreading of neurodegenerative pathology via neuron-to-neuron transmission of beta-amyloid. J Neurosci 32: 87678777. https://doi.org/10.1523/JNEUROSCI.0615-12.2012

Nečas D, Klapetek P (2012) Gwyddion: an open-source software for SPM data analysis. Central Eur J Phys 10: 181-188. https://doi.org/ https://doi.org/10.2478

Nery LR, Eltz NS, Hackman C, Fonseca R, Altenhofen S, Guerra HN, Freitas VM, Bonan CD, Vianna MR (2014) Brain intraventricular injection of amyloid-beta in zebrafish embryo impairs cognition and 
increases tau phosphorylation, effects reversed by lithium. PLoS One 9: e105862. https://doi.org/10.1371/journal.pone.0105862

Nordberg G, Fowler B, Nordberg M, eds. (2015) Handbook on the Toxicology of Metals, Elsevier

Owen MC, Gnutt D, Gao M, Wärmländer SKTS, Jarvet J, Gräslund A, Winter R, Ebbinghaus S, Strodel B (2019) Effects of in vivo conditions on amyloid aggregation. Chem Soc Rev 48: 3946-3996. https:// doi.org/10.1039/c8cs00034d

Pan Y, Short JL, Newman SA, Choy KHC, Tiwari D, Yap C, Senyschyn D, Banks WA, Nicolazzo JA (2018) Cognitive benefits of lithium chloride in APP/PS1 mice are associated with enhanced brain clearance of beta-amyloid. Brain Behav Immun 70: 36-47. https://doi.org/10.1016/j.bbi.2018.03.007

Priebe GA, Kanzawa MM (2020) Reducing the progression of Alzheimer's disease in Down syndrome patients with micro-dose lithium. Med Hypotheses 137: 109573. https://doi.org/10.1016/j. mehy.2020.109573

Prince M, Wimo A, Guerchet M, Ali G-C, Wu Y-T, Prina M (2015) World Alzheimer Report 2015 - The Global Impact of Dementia. London, UK

Querfurth HW, LaFerla FM (2010) Alzheimer's disease. N Engl J Med 362: 329-344. https://doi.org/10.1056/NEJMra0909142

Rangachari V, Moore BD, Reed DK, Sonoda LK, Bridges AW, Conboy E, Hartigan D, Rosenberry TL (2007) Amyloid-beta(1-42) rapidly forms protofibrils and oligomers by distinct pathways in low concentrations of sodium dodecylsulfate. Biochemistry 46: 1245112462. https://doi.org/10.1021/bi701213s

Regen F, Hellmann-Regen J, Costantini E, Reale M (2017) Neuroinflammation and Alzheimer's disease: implications for microglial activation. Curr Alzheimer Res 14: 1140-1148. https://doi.org/10.2174/1 567205014666170203141717

Rocha NKR, Themoteo R, Brentani H, Forlenza OV, De Paula VJR (2020) Neuronal-glial interaction in a triple-transgenic mouse model of Alzheimer's disease: gene ontology and lithium pathways. Front Neurosci 14: 579984. https://doi.org/10.3389/fnins.2020.579984

Rockenstein E, Torrance M, Adame A, Mante M, Bar-on P, Rose JB, Crews L, Masliah E (2007) Neuroprotective effects of regulators of the glycogen synthase kinase-3beta signaling pathway in a transgenic model of Alzheimer's disease are associated with reduced amyloid precursor protein phosphorylation. J Neurosci 27: 1981-1991. https://doi.org/10.1523/JNEUROSCI.4321-06.2007

Roos PM (2014) Osteoporosis in neurodegeneration. I Trace Elem Med Biol 28: 418-421. https://doi.org/10.1016/j.jtemb.2014.08.010

Ryves WJ, Harwood AJ (2001) Lithium inhibits glycogen synthase kinase-3 by competition for magnesium. Biochem Biophys Res Commun 280: 720-725. https://doi.org/10.1006/bbrc.2000.4169

Salata R, Klein I (1987) Effects of lithium on the endocrine system: a review. J Lab Clin Med 110: 130-136. PMID: 3298507

Sardar Sinha M, Ansell-Schultz A, Civitelli L, Hildesjo C, Larsson M, Lannfelt L, Ingelsson M, Hallbeck M (2018) Alzheimer's disease pathology propagation by exosomes containing toxic amyloid-beta oligomers. Acta Neuropathol 136: 41-56. https://doi.org/10.1007/ s00401-018-1868-1

Sarroukh R, Goormaghtigh E, Ruysschaert JM, Raussens V (2013) ATR-FTIR: a "rejuvenated" tool to investigate amyloid proteins. Biochim Biophys Acta 1828: 2328-2338. https://doi.org/10.1016/i. bbamem.2013.04.012

Selkoe DJ, Hardy J (2016) The amyloid hypothesis of Alzheimer's disease at 25 years. EMBO Mol Med 8: 595-608. https://doi. org/10.15252/emmm.201606210

Sellers J, Tyrer P, Whiteley A, Banks DC, Barer DH (1982) Neurotoxic effects of lithium with delayed rise in serum lithium levels. $\mathrm{Br} J$ Psychiatry 140: 623-625. https://doi.org/10.1192/bjp.140.6.623

Sengupta U, Nilson AN, Kayed R (2016) The role of amyloid-beta oligomers in toxicity, propagation, and immunotherapy. EBioMedicine 6 42-49. https: / / doi.org/10.1016/j.ebiom.2016.03.035

Sofola-Adesakin O, Castillo-Quan JI, Rallis C, Tain LS, Bjedov I, Rogers I, Li L, Martinez P, Khericha M, Cabecinha M, Bahler J, Partridge L (2014) Lithium suppresses Abeta pathology by inhibiting translation in an adult Drosophila model of Alzheimer's disease. Front Aging Neurosci 6: 190. https://doi.org/10.3389/fnagi.2014.00190

Stefaniak E, Bal W (2019) Cu(II) binding properties of N-truncated abeta peptides: in search of biological function. Inorg Chem $\mathbf{5 8}$ 13561-13577. https://doi.org/10.1021/acs.inorgchem.9b01399

Sutherland C, Duthie AC (2015) Invited commentary on ... Lithium treatment and risk for dementia in adults with bipolar disorder. $\mathrm{Br}$ J Psychiatry 207: 52-54. https://doi.org/10.1192/bjp.bp.114.161729

Szabo ST, Harry GJ, Hayden KM, Szabo DT, Birnbaum L (2016) Comparison of metal levels between postmortem brain and ventricular fluid in Alzheimer's disease and nondemented elderly controls. Toxicol Sci 150: 292-300. https://doi.org/10.1093/toxsci/kfv325

Tiiman A, Luo J, Wallin C, Olsson L, Lindgren J, Jarvet J, Roos PM, Sholts SB, Rahimipour S, Abrahams JP, Karlström AE, Gräslund A, Wärmländer SKTS (2016) Specific binding of $\mathrm{Cu}(\mathrm{II})$ ions to amyloid-beta peptides bound to aggregation-inhibiting molecules or
SDS micelles creates complexes that generate radical oxygen species. I Alsheimers Dis 54: 971-982. https://doi.org/10.3233/JAD-160427 Trujillo-Estrada L, Jimenez S, De Castro V, Torres M, Baglietto-Vargas D, Moreno-Gonzalez I, Navarro V, Sanchez-Varo R, SanchezMejias E, Davila JC, Vizuete M, Gutierrez A, Vitorica J (2013) In vivo modification of Abeta plaque toxicity as a novel neuroprotective lithium-mediated therapy for Alzheimer's disease pathology. Acta Neuropathol Commun 1: 73. https://doi.org/10.1186/2051-5960-1-73

Velosa J, Delgado A, Finger E, Berk M, Kapczinski F, de Azevedo Cardoso T (2020) Risk of dementia in bipolar disorder and the interplay of lithium: a systematic review and meta-analyses. Acta Psychiatr Scand 141: 510-521. https://doi.org/10.1111/acps.13153

Vosough F, Barth A (2021) Characterization of homogeneous and heterogeneous amyloid- $\beta 42$ oligomer preparations with biochemical methods and infrared spectroscopy reveals a correlation between infrared spectrum and oligomer size. ACS Chem Neurosci 12: 473-488. https://doi.org/10.1021/acschemneuro.0c00642

Wallin C, Friedemann M, Sholts SB, Noormagi A, Svantesson T, Jarvet J, Roos PM, Palumaa P, Gräslund A, Wärmländer SKTS (2020) Mercury and Alzheimer's Disease: $\mathrm{Hg}$ (II) ions display specific binding to the amyloid-beta peptide and hinder its fibrillization. Biomolecules 10: 44. https://doi.org/10.3390/biom10010044

Wallin C, Jarvet J, Biverstål H, Wärmländer S, Danielsson J, Gräslund A, Abelein A (2020) Metal ion coordination delays amyloidbeta peptide self-assembly by forming an aggregation-inert complex. J Biol Chem 295: 7224-7234. https://doi.org/10.1074/jbc. RA120.012738

Wallin C, Kulkarni YS, Abelein A, Jarvet J, Liao Q, Strodel B, Olsson L, Luo J, Abrahams JP, Sholts SB, Roos PM, Kamerlin SC, Gräslund A, Wärmländer SK (2016) Characterization of $\mathrm{Mn}(\mathrm{II})$ ion binding to the amyloid-beta peptide in Alzheimer's disease. J Trace Elem Med Biol 38: 183-193. https://doi.org/10.1016/j.jtemb.2016.03.009

Wallin C, Sholts SB, Österlund N, Luo J, Jarvet J, Roos PM, Ilag L, Gräslund A, Wärmländer S (2017) Alzheimer's disease and cigarette smoke components: effects of nicotine, PAHs, and $\mathrm{Cd}(\mathrm{II}), \mathrm{Cr}(\mathrm{III})$, $\mathrm{Pb}(\mathrm{II}), \mathrm{Pb}(\mathrm{IV})$ ions on amyloid-beta peptide aggregation. Sci Rep 7: 14423. https://doi.org/10.1038/s41598-017-13759-5

Wang X, Wang W, Li L, Perry G, Lee HG, Zhu X (2014) Oxidative stress and mitochondrial dysfunction in Alzheimer's disease. Biochim Biophys Acta 1842: 1240-1247. https://doi.org/10.1016/j. bbadis.2013.10.015

Wang ZX, Tan L, Wang HF, Ma J, Liu J, Tan MS, Sun JH, Zhu XC, Jiang T, Yu JT (2015) Serum iron, zinc, and copper levels in patients with Alzheimer's disease: a replication study and meta-analyses. J Aląheimers Dis 47: 565-581. https://doi.org/10.3233/JAD143108

Wen J, Sawmiller D, Wheeldon B, Tan J (2019) A review for lithium: pharmacokinetics, drug design, and toxicity. CNS Neurol Disord Drug Targets 18: 769-778. https://doi.org/10.2174/1871527318666191114 095249

Wilson EN, Do Carmo S, Welikovitch LA, Hall H, Aguilar LF, Foret MK, Iulita MF, Jia DT, Marks AR, Allard S, Emmerson JT, Ducatenzeiler A, Cuello AC (2020) NP03, a microdose lithium formulation, blunts early amyloid post-plaque neuropathology in McGill-R-Thy1-APP Alzheimer-like transgenic rats. I Alzheimers Dis 73: 723-739. https://doi.org/10.3233/JAD-190862

Wärmländer S, Tiiman A, Abelein A, Luo J, Jarvet J, Söderberg KL, Danielsson J, Gräslund A (2013) Biophysical studies of the amyloid beta-peptide: interactions with metal ions and small molecules. Chembiochem 14: 1692-1704. https://doi.org/10.1002/cbic.201300262

Wärmländer SKTS, Österlund N, Wallin C, Wu J, Luo J, Tiiman A, Jarvet J, Gräslund A (2019) Metal binding to the Amyloid- $\beta$ peptides in the presence of biomembranes: potential mechanisms of cell toxicity. J Biol Inorg Chem 24: 1189-1196. https://doi.org/10.1007/ s00775-019-01723-9

Xiang J, Cao K, Dong YT, Xu Y, Li Y, Song H, Zeng XX, Ran LY, Hong W, Guan ZZ (2020) Lithium chloride reduced the level of oxidative stress in brains and serums of APP/PS1 double transgenic mice via the regulation of GSK3beta/Nrf2/HO-1 pathway. Int J Neurosii 130: 564-573. https://doi.org/10.1080/00207454.2019.168 8808

Yu F, Zhang Y, Chuang DM (2012) Lithium reduces BACE1 overexpression, beta amyloid accumulation, and spatial learning deficits in mice with traumatic brain injury. I Neurotrauma 29: 2342-2351. https://doi.org/10.1089/neu.2012.2449

Zhao L, Gong N, Liu M, Pan X, Sang S, Sun X, Yu Z, Fang Q, Zhao N, Fei G, Jin L, Zhong C, Xu T (2014) Beneficial synergistic effects of microdose lithium with pyrroloquinoline quinone in an Alzheimer's disease mouse model. Neurobiol Aging 35: 2736-2745. https:// doi.org/10.1016/j.neurobiolaging.2014.06.003

Österlund N, Kulkarni YS, Misiaszek AD, Wallin C, Krüger DM, Liao Q, Mashayekhy Rad F, Jarvet J, Strodel B, Wärmländer SKTS, Ilag LL, Kamerlin SCL, Gräslund A (2018) Amyloid-beta peptide interactions with amphiphilic surfactants: electrostatic and hydrophobic effects. ACS Chem Neurosci 9: 1680-1692. https://doi.org/10.1021/ acschemneuro.8b00065 